NBER WORKING PAPER SERIES

\title{
THE EFFECTS OF MANDATORY SEATBELT LAWS ON SEATBELT USE, MOTOR VEHICLE FATALITIES, AND CRASH-RELATED INJURIES AMONG YOUTHS
}

\author{
Christopher S. Carpenter \\ Mark Stehr \\ Working Paper 13408 \\ http://www.nber.org/papers/w13408 \\ NATIONAL BUREAU OF ECONOMIC RESEARCH \\ 1050 Massachusetts Avenue \\ Cambridge, MA 02138 \\ September 2007
}

We are grateful to Steven Kinchen and Shari Shanklin at the Centers for Disease Control for assistance in obtaining the data. Daniel Eisenberg, Anindya Sen, and anonymous referees provided very useful comments. All errors are our own. The views expressed herein are those of the author(s) and do not necessarily reflect the views of the National Bureau of Economic Research.

(C) 2007 by Christopher S. Carpenter and Mark Stehr. All rights reserved. Short sections of text, not to exceed two paragraphs, may be quoted without explicit permission provided that full credit, including (c) notice, is given to the source. 
The Effects of Mandatory Seatbelt Laws on Seatbelt Use, Motor Vehicle Fatalities, and Crash-Related Injuries among Youths

Christopher S. Carpenter and Mark Stehr

NBER Working Paper No. 13408

September 2007

JEL No. I1

\begin{abstract}
We provide the first comprehensive assessment of the effects of mandatory seatbelt laws on self-reported seatbelt use, highway fatalities, and crash-related injuries among high school age youths using data from the Centers for Disease Control's (CDC) national, state, and local Youth Risk Behavior Surveys (YRBS) and the Fatality Analysis Reporting System (FARS) from 1991 to 2005, a period spanning over 20 changes in state seatbelt laws. Our quasi-experimental approaches isolate the independent effects of seatbelt laws net of demographic characteristics, area and year fixed effects, and smooth area-specific trends. Across all data sources, we find consistent evidence that state mandatory seatbelt laws -- particularly those permitting primary enforcement -- significantly increased seatbelt use among high school age youths by 45-80 percent, primarily at the extensive margin. Unlike previous research for adults, however, we find evidence against the selective recruitment hypothesis: seatbelt laws had consistently larger effects on those most likely to be involved in traffic accidents (drinkers, alcohol-involved drivers). We also find that mandatory seatbelt laws significantly reduced traffic fatalities and serious injuries resulting from fatal crashes by 8 and 9 percent, respectively. Our results suggest that if all states had primary enforcement seatbelt laws then regular youth seatbelt use would be nearly universal and youth fatalities would fall by about 120 per year.
\end{abstract}

Christopher S. Carpenter

University of California, Irvine

The Paul Merage School of Business

$443 \mathrm{SB}$

Irvine, CA 92697-3125

and NBER

kittc@uci.edu

Mark Stehr

Drexel University

LeBow College of Business

Matheson Hall 504E

3141 Chestnut Street

Philadelphia, PA 19104-2875

stehr@drexel.edu 


\section{Introduction}

An enormous body of research shows that seatbelts save lives, in large part by reducing the severity of injuries in traffic collisions (NHTSA 2003). States began adopting mandatory seatbelt laws in the 1980's, and research has shown that these laws have been effective at reducing highway fatalities, primarily by inducing very large increases in regular seatbelt use among adults (Cohen and Einav 2003, Dee 1999 and others). ${ }^{1}$ Research has also shown that laws permitting primary enforcement of seatbelt laws whereby police authorities can cite violators of the seatbelt law even in the absence of other violations - have been relatively more effective than weaker laws mandating only secondary enforcement (see, for example, Houston and Richardson 2006, and others).

In contrast to the large body of evidence on the effects of mandatory seatbelt laws on adults, there is very little evaluation research focusing on youths. Youths, however, are of heightened interest in the context of seatbelt use for two key reasons. First, rates of seatbelt use among high school age youths are much lower than the associated rates for adults (Womack et al. 1997, Williams et al. 2003, and others). In our national data covering the period 1991-2005 (described below), only about one third of high school age youths report always wearing a seatbelt when riding in someone else's car, while data from the University of Michigan's Monitoring the Future Study over the period 19862000 show that only one quarter of high school seniors report always wearing a seatbelt when driving a car. These figures are less than half the associated rate for adults according to surveys fielded by the National Highway Transportation Safety Administration (NHTSA), which produce seatbelt use rates of over $70 \%$ for adults by

\footnotetext{
${ }^{1}$ A similar relationship has also been documented throughout provinces in Canada. See, for example, Sen 2001 and 2006.
} 
2001. Second, traffic fatalities are disturbingly common among youths, both in absolute and relative terms: fatal crash rates of youths age 16-19 are about four times higher than the associated rates for older adults age 25-69 (NHTSA 2003), and motor vehicle crashes are the leading cause of death for 15-20 year olds in the United States (according to 2002 mortality data from the National Center for Health Statistics). Finally, previous research has argued that youths are unlikely to be strongly responsive to seatbelt laws because of "selective recruitment" - whereby those most likely to be in accidents are those least likely to increase seatbelt use in response to a law. These facts heighten the importance of understanding the relationship between seatbelt laws and seatbelt use among youths.

We provide the first comprehensive evaluation of the effects of mandatory seatbelt laws on youth seatbelt use, traffic fatalities, and crash-related injuries. To do so, we use area-identified versions of the 1991-2005 national Youth Risk Behavior Surveys (YRBS), the 1993-2005 state YRBS, and the 1993-2005 local YRBS, all coordinated by the Centers for Disease Control (CDC). The national YRBS microdata provide the benefit of large sample sizes, multiple meaningful measures of seatbelt use, the ability to directly control for individual demographic characteristics, and the ability to test hypotheses about selective recruitment among youths using information on other risky behaviors such as drinking and alcohol-involved driving. The state and local YRBS samples improve on previous research because the majority of these surveys are designed to be representative of the larger high school student population. ${ }^{2}$ We complement the analyses of self-reported seatbelt use - which may suffer from endogenous reporting bias - with more objectively measured evidence on traffic fatalities and crash-related injuries

\footnotetext{
${ }^{2}$ For a similar example of the state and local representative YRBS data used in this way, see Carpenter and Cook (2007, forthcoming).
} 
using data from the 1991-2005 Fatality Analysis Reporting System (FARS). ${ }^{3}$ Our data span a time period that witnessed over 20 changes in state seatbelt laws. Because of this, our models are able to support unrestricted controls for area (city or state) and year fixed effects, resulting in difference-in-differences models of the effect of seatbelt laws on youth outcomes. Our most preferred specifications also account for smooth area-specific linear trends which are consistently significant predictors of the youth outcomes we study.

The results from these four independent data sources return consistent evidence that mandatory seatbelt laws permitting primary enforcement (i.e. where authorities need only observe the seatbelt violation to issue a citation) have significantly increased seatbelt use among high school age youths by about $45-80$ percent. The FARS data also indicate that adoption of a primary enforcement seatbelt law significantly reduces youth fatalities by about 8 percent and serious crash-related injuries by about 9 percent relative to the sample means. Across all outcomes, we find a lesser role - but often still a statistically significant one - for seatbelt laws permitting only secondary enforcement (where another violation must be observed before a seatbelt citation can be issued). Finally, unlike previous research, we find evidence against the selective recruitment hypothesis: among high school youths, those most likely to be involved in accidents (drinkers, binge drinkers, alcohol-involved drivers) have relatively larger seatbelt use increases in response to seatbelt laws.

\footnotetext{
${ }^{3}$ Endogenous reporting bias refers to the fact that youths may be more likely to falsely report increased seatbelt use when stricter seatbelt laws are adopted due to the increased stigma of riding unbelted. In the extreme, our seatbelt use models could return evidence of a seatbelt law induced increase even in the absence of any true behavioral change. Analyzing more objectively measured fatalities and injuries therefore provides important complementary evidence on seatbelt law effectiveness. These outcomes are also independently interesting as they are more likely to motivate public policy.
} 
In addition to providing the literature's first comprehensive analysis of seatbelt laws on youth outcomes, our research advances the literature in several other key ways. First, we analyze the most recent data available - through 2005. Although the most recent relevant studies have examined data through 2002, fully 10 states have adopted an initial seatbelt law or upgraded their existing law since 2002. As such, estimates using the most current data are highly relevant and useful for current state policy debates. Second, we consider both traffic fatalities and serious crash-related injuries resulting from fatal crashes in our analyses of health outcomes. Most previous evaluation studies consider only the former. Third, our analyses of the national YRBS microdata uncover new evidence regarding how mandatory seatbelt laws increase seatbelt use: specifically, we find that the laws mainly affect the extensive margin of seatbelt use (increasing any seatbelt participation) rather than the intensive margin (increasing use among users). And finally, our fatality and injury analyses use more precise information on the timing of seatbelt laws by matching them by exact date of implementation instead of assigning fractional values for mid-year changes.

The paper proceeds as follows: Section 2 briefly describes the previous literature, and Section 3 describes the data and empirical approach. Section 4 presents the results, and Section 5 discusses and concludes.

\section{Previous Literature}

Numerous studies have evaluated the effects of state seatbelt laws on overall fatalities and adult seatbelt use. These studies have shown that adoption of a mandatory seatbelt law significantly increases adult seatbelt use and reduces traffic fatalities (for recent 
examples, see Cohen and Einav 2003, Houston and Richardson 2005 and 2006, and others). These studies also generally agree that primary enforcement laws have been more effective than weaker secondary enforcement laws. Finally, there is evidence of selective recruitment among adults: those most likely to be involved in accidents are the least likely to take up seatbelt use in response to a mandatory seatbelt law.

A handful of studies have examined seatbelt laws and fatalities among youths. Eisenberg (1999) studied the effects of .08 BAC laws on fatalities and included a seatbelt law variable in his models. He estimates that a state seatbelt law significantly reduces fatal crashes among youths under age 21 by 15 percent over 1982-2000. Similarly, Dee and Evans (2001) estimate fatality reductions among 16-17 year olds of about 8 percent for primary enforcement laws and about 4 percent for secondary enforcement laws over the 1977-1992 period, while Dee et al. (2005) focus on graduated driver licensing programs but obtain similar seatbelt law estimates to Dee and Evans (2001) over the period 1992-2002 that are not statistically significant.

Importantly, none of these studies examines the effects of seatbelt laws on selfreported seatbelt use among high school age youths. ${ }^{4}$ Instead, the existing literature on the determinants of self-reported youth seatbelt use has been largely descriptive. ${ }^{5}$ Only one previous study has directly considered the effects of state seatbelt laws on youth

\footnotetext{
${ }^{4}$ Dee and Evans (2001) present results for BRFSS 18 and 19 year olds, but the BRFSS does not sample individuals younger than age 18. Notably, both the BRFSS and the YRBS are coordinated by the Centers for Disease Control.

${ }^{5}$ Williams et al. (2002) observed seatbelt use rates among youths being dropped off at schools in the morning and driving to football games in the evening at 12 schools in Connecticut and Massachusetts, finding that youth seatbelt use rates were lower than those of the adults who were driving them. McCartt and Shabanova (2002) provide a descriptive analysis of seatbelt use by teenagers killed in fatal traffic accidents and find that belt use rates were higher among youths in states with primary enforcement seatbelt laws compared to states with only secondary enforcement. This study did not explicitly evaluate the effects of the laws, however, and suffers from a usual limitation of fatality data (i.e. if the laws have independent
} 
seatbelt use. O'Malley and Wagenaar (2005) use data from the Monitoring the Future (MTF) study and relate the presence of state seatbelt laws mandating secondary enforcement to self-reported seatbelt use by youths. Their analysis is based on pre-post differences in belt use within states and includes controls for secular trends. They find very large effects of secondary enforcement laws on the likelihood that high school seniors report "always" wearing a seatbelt when they drive or ride as a passenger, on the order of 14 percentage points (i.e. a 70 percent effect off the pre-reform mean of 20.5 percent for the passenger seatbelt variable, see their Table 2).

There are, however, some limitations to the O’Malley and Wagenaar (2004) study which motivate further analysis of the effects of seatbelt laws on youths. First, the MTF data are not designed to be representative of the sampled states. Our data, described below, allow us to estimate models that restrict attention to data from state and local YRBS surveys that were explicitly designed to produce representative estimates, increasing the confidence we have in our estimates. Second, the O'Malley and Wagenaar study only considered high school seniors due to the nature of the MTF sampling frame. Younger youths are clearly of interest, however, as there may be different underlying effects of the seatbelt laws by age. ${ }^{6}$ Third, O’Malley and Wagenaar examine secondary enforcement seatbelt laws but do not account for the numerous adoptions of stricter primary enforcement laws over their time period. Below, we show this distinction to be important. Finally, O’Malley and Wagenaar do not study more objectively measured outcomes such as traffic fatalities or injuries. We improve on these limitations below.

effects on crashes or fatalities, then observed belt use rates among fatally injured youths conflates multiple underlying relationships). 


\section{Data Description and Research Design}

We use four main sources of data to evaluate the effects of mandatory seatbelt laws on youths. First, we use the national, state, and local Youth Risk Behavior Surveys (YRBS) from the Centers for Disease Control which provide us information on self-reported seatbelt use by high school youths across the US. We also use data from the Fatality Analysis Reporting System (FARS) to provide information on fatalities and crash-related injuries. The FARS analyses complement the YRBS analyses by providing information on outcomes that are more objectively measured and are therefore less subject to concerns about endogenous reporting bias. Throughout, we consider data from 19912005, a period spanning over 20 changes in state seatbelt laws. ${ }^{7}$

\section{1: National, State, and Local Youth Risk Behavior Surveys (YRBS)}

To estimate the effect of state mandatory seatbelt laws on youth seatbelt use, we employ restricted use area-identified versions of the 1991-2005 national Youth Risk Behavior Surveys, in conjunction with the independent state and local versions of the YRBS. The national surveys - which are distinct from the state and local surveys and were not designed to be representative below the national level - are coordinated every other year by the Centers for Disease Control and are administered to high school students at school in the spring. ${ }^{8}$ These data provide standard demographic characteristics, information on

\footnotetext{
${ }^{6}$ McCartt and Shabanova (2002), for example, show that there is a noticeable age gradient in seatbelt use among youths who were fatally injured in car crashes: 18 year olds were less likely to have been belted compared to 17 and 16 year olds.

${ }^{7}$ Most of these law changes reflect "upgrades" from states with existing laws mandating secondary enforcement to laws mandating primary enforcement.

${ }^{8}$ The fact that the YRBS data are administered at school induces potential sample selection bias because dropout behavior by older youths and/or absenteeism may be important. If there is selective recruitment in
} 
seatbelt use, and the state of survey (requested in a restricted use version of the data directly through $\mathrm{CDC}$ ). We restrict attention to youths with no missing data on the demographic characteristics or seatbelt use questions, yielding well over 110,000 youths. ${ }^{9}$

The state and local YRBS data are coordinated by public health officials in the respective states and include standard questions that exactly mirror those in the national survey. ${ }^{10}$ The majority of these state and local efforts were designed to be representative of the state or locality in question, and below we present estimates from the full sample and the subsample of representative surveys. ${ }^{11}$ To our knowledge, these weighted state and local surveys are the only consistent state/year panel of representative data on youth seatbelt use. ${ }^{12}$ The coverage of state surveys is extensive (see Appendix Table 1), while the local YRBS modules are generally concentrated in large urban centers such as Los Angeles, New York City, Boston, and Chicago (see Appendix Table 2 for a complete list). The state and local YRBS are fielded every other year, and these estimates are published in Morbidity and Mortality Weekly Report. Included in each report are various

the effects of seatbelt laws, the omission of high school dropouts and absent students could impart an upward bias in our seatbelt use estimates (i.e. if those least likely to take up seatbelt use in the presence of a law are missing from our sample). Below, we show that there is evidence against selective recruitment; as such, omission of these students likely imparts a downward bias to our estimates. To address the issue of dropout behavior, below we estimated seatbelt use models for younger youths (e.g. age 14-16) in the national YRBS data and found similarly sized increases in seatbelt use.

${ }^{9}$ Only 342 youths did not respond to the question about seatbelt use. This is only about .3 percent of the sample.

${ }^{10}$ It is important to reiterate that the national survey is not composed of the local and state surveys. Each state and local survey is an independent sample, as is the biennial national survey.

${ }^{11}$ Throughout, however, we drop any state/year or city/year observations in which the CDC determined the response rates to be too low to be deemed reliable, regardless of whether the survey was designed to be representative.

${ }^{12}$ The other main data source on youth risk behaviors - the Monitoring the Future Study - is not designed to be representative of each participating state. Another possible source of data we considered were parental reports of youth seatbelt use from the CDC's Behavioral Risk Factor Surveillance System (BRFSS), which is designed to be state representative of adults. Unfortunately, the questions changed multiple times over the sample period and were not consistently part of the core questionnaire. In some years parents were asked about the oldest child, while in other years the parents were asked about the youngest child in the household. While both are independently interesting, we are unable to create a consistent series of parental self reports for either high school age youths or younger youths. 
characteristics for each site. Specifically, we observe: the relevant sample size on which the estimates are based; whether the survey was unweighted or weighted to be representative; the overall, student, and school response rates; the fraction of the school population that is white, black, other race, and Hispanic; the fraction of the population that is in each grade (9-12); and an aggregate outcome representing seatbelt surveillance.

Each year the YRBS core questionnaire has included a question about usual seatbelt use. Specifically, the question reads "How often do you wear a safety belt when riding in someone else's car?", and the response options are "always", "often", "sometimes", "rarely", and "never". For surveillance purposes, two constructs are often used. First, the Centers for Disease Control publishes in their main report the fraction of youths who respond "rarely" or "never" to this question, a variable we call "infrequent use". Because we do not have access to the underlying microdata on which the state and local YRBS figures are based, we necessarily examine this outcome. The national microdata, however, allow us to consider measures that are more routinely used in the literature on adult seatbelt use: specifically, we consider as an outcome whether a youth reports she "always" wears a seatbelt (Dee 1999). Finally, we follow Cohen and Einav (2003) to create a weighted continuous measure of seatbelt use for the national YRBS data. ${ }^{13}$

The YRBS seatbelt question is limited by the fact that it refers to seatbelt use when in someone else's car. It would clearly have been useful to have information on seatbelt use among youths in the context of their own driving. This is unlikely to be a serious problem in our analysis, since seatbelt use when driving is likely to be highly

\footnotetext{
${ }^{13}$ Specifically, we assign a weight of 0 to "never" responses, .1 to "rarely" responses, .3 to "sometimes" responses, .75 to "often" responses, and 1 to "always" responses.
} 
correlated with seatbelt use as a passenger. ${ }^{14}$ As evidence of this, we note the O'Malley and Wagenaar study shows extremely similar mean seatbelt use rates for these two distinct measures in the MTF (2.85 on the continuous scale for seatbelt use when driving and 2.78 for seatbelt use when riding as a passenger). Of course, our measure of seatbelt use is independently interesting, as many of the high school age youths are under their state's minimum driving age. ${ }^{15}$ Understanding seatbelt behavior among these youths for whom passenger use is the only meaningful measure is important.

To estimate the effect of the mandatory seatbelt laws, we follow previous approaches in the economics and policy evaluation literature. Specifically, we estimate reduced form models of youth seatbelt use as a function of state seatbelt laws, other state characteristics and policies that may be relevant to youth driving, unrestricted area and year fixed effects, and linear area-specific time trends. For our state and local YRBS analyses, we estimate separate weighted least squares models where the weights are the relevant sample sizes on which the seatbelt use rates are based. This amounts to estimation of the following:

(1) $\mathrm{Y}_{\mathrm{at}}=\beta_{0}+\beta_{1} \mathrm{X}_{\mathrm{at}}+\beta_{2}(\text { Primary Seatbelt Law })_{\mathrm{at}}+\beta_{3}(\text { Secondary Seatbelt Law })_{\mathrm{at}}+$

$$
\beta_{4} \mathrm{Z}_{\mathrm{at}}+\beta_{5} \text { Area }+\beta_{6} \text { Year }+\varepsilon_{\mathrm{at}}
$$

\footnotetext{
${ }^{14}$ Unfortunately, questions about seatbelt use while driving were only asked in the 2001 and 2003 waves. Among drivers, these variables are highly positively correlated (above .7).

${ }^{15}$ Also, some state laws are explicitly related to seatbelt use while a passenger (as opposed to while driving). Some state graduated driver licensing programs, for example, explicitly require a young driver to ensure that all passengers are restrained or otherwise reinforce seatbelt requirements (e.g. Tennessee, Utah, North Carolina, and Wisconsin). We do not make use of this variation in the analyses below, however, because we are not aware of a source that consistently documents these provisions for all states over our sample period. We also do not distinguish among laws that set different enforcement standards for youths of different ages based on where in the vehicle they are seated because the YRBS questions do not distinguish between front or rear seats. Also, we do not observe exact ages of youths in our preferred state or local YRBS data, so we cannot exactly match for each individual whether she is covered by a particular seatbelt law. As such, our reduced form estimates can best be though of as the effects of mandatory seatbelt laws on the high school age population.
} 
where a denotes area (city or state) and $t$ denotes survey year. Since we only observe the aggregate outcomes reported in the $M M W R$ publications, $\mathrm{Y}_{\text {at }}$ is the fraction of the sample reporting infrequent use (i.e. "rarely" or "never" wears a seatbelt when riding in a car). $\mathrm{X}_{\mathrm{at}}$ is a vector of sample characteristics that includes: overall response rate, school response rate, student response rate, percent grade 10, percent grade 11, percent grade 12, percent black, percent other race, and percent Hispanic. We also include in $\mathrm{X}$ the state unemployment rate. $\mathrm{Z}$ is a vector of motor vehicle safety laws and alcohol control policies that may influence driving and seatbelt use behaviors, including: the presence of a graduated driver licensing program with an intermediate phase, the presence of a Zero Tolerance drunk driving law, the presence of a $.08 \mathrm{BAC}$ per se drunk driving law, and dummy variables for speed limits $(65 \mathrm{mph}$, and $70 \mathrm{mph}$ or greater) pertaining to cars on rural interstates. Area is a vector of either state dummies or city dummies, depending on the dataset. Year is a vector of survey year dummies. Primary (Secondary) Seatbelt Law is an indicator variable equal to one if the respondent lives in a state that has a primary (secondary) seatbelt law in place at the time of interview. ${ }^{16}$ For states that upgrade from secondary seatbelt laws to primary seatbelt laws, we turn off the secondary seatbelt law indicator when the primary seatbelt law becomes effective. ${ }^{17}$

The coefficient of interest, $\beta_{2}\left(\beta_{3}\right)$, captures the relative effect of the primary (secondary) seatbelt law on youth seatbelt use by comparing within area changes in state

\footnotetext{
${ }^{16}$ Although we do not observe the actual interview date, we do know that the surveys were administered in the spring in odd-numbered calendar years. In practice, this allows us to know for each observation whether a seatbelt law is in place (given the timing of seatbelt law adoptions).

${ }^{17}$ For effective dates of seatbelt laws, we use the published dates from Cohen and Einav (2003, Table 1), updated with lexis-nexis searches and documents from the Insurance Institute for Highway Safety (IIHS). For GDL programs, we use the published dates from Dee et al. (2005), updated with lexis-nexis searches and documents from IIHS. Information on .08 BAC effective dates comes from published NHTSA reports (www.nhtsa.gov), while state unemployment rates come from the Bureau of Labor Statistics. Speed limits were provided by Tom Dee through 2000, and we updated them through 2005 with information from IIHS.
} 
seatbelt use outcomes coincident with policy adoption to the associated outcomes for youths in states/cities that did not experience a policy change in that year. In further models we also allow for linear area trends. This amounts to including a variable called Trend which equals 1 in 1991, 3 in 1993, and so forth, multiplied by each state or city fixed effect. In these models, the coefficients of interest reflect deviations in youth seatbelt use from a smooth linear trend, coincident with adoption of the state seatbelt law. Standard errors are clustered at the state level throughout (Bertrand, Duflo, and Mullainathan 2004). ${ }^{18}$

Estimation of the effects of state seatbelt laws with the national YRBS microdata follows a similar approach, though we augment the models to take advantage of the individual demographic information and the richer set of outcomes (since, unlike the state and local samples, we observe the entire distribution of responses to the seatbelt question). For comparability to the state and local analyses, we create an indicator variable equal to one for youths who report "rarely" or "never" wearing a seatbelt when riding in someone else's car (i.e. "infrequent" use). Estimation of the effects of seatbelt laws proceeds by probit:

(2) $Y_{\text {ist }}=\beta_{0}+\beta_{1} X_{\text {ist }}+\beta_{2}(\text { Primary Seatbelt Law })_{\mathrm{st}}+\beta_{3}(\text { Secondary Seatbelt Law })_{\mathrm{st}}+$ $\beta_{4} Z_{\text {st }}+\beta_{5}$ State $+\beta_{6}$ Year $+\varepsilon_{\text {ist }}$

where all variables in $\mathrm{Z}$ are as described above. Here, $\mathrm{Y}_{\text {ist }}$ is an indicator for infrequent seatbelt use. $X_{i s t}$ is a vector of individual demographic characteristics, including dummies for: female, black, other race, Hispanic, grade, and age. State is a vector of state dummies, and Year is a vector of year dummies. Again, $\beta_{2}$ and $\beta_{3}$ are the

\footnotetext{
${ }^{18} \mathrm{We}$ also experimented with city level clustering for the local YRBS models. Standard errors were extremely similar and are available upon request.
} 
coefficients of interest. Because we observe the exact response to the seatbelt question, we also estimate probit models of the likelihood the youth reports she "always" wears a seatbelt, as well as OLS models for the continuous seatbelt variable (described above).

Note that in our models the seatbelt coefficients are estimated relative to state/year observations that have no seatbelt law in effect. This is problematic for our analysis of the local YRBS data since the cities represented in these data are almost exclusively concentrated in states that had adopted some kind of seatbelt law by 1993; as such, for the local analysis we estimate the effect of the primary enforcement seatbelt laws. ${ }^{19}$ Although the time period covered for the state analysis is the same as the local analysis, we have a much wider coverage of states in the state YRBS analysis, including states that had no law in effect by $1993 .^{20}$ Therefore, our analyses of state and national YRBS data can support meaningful estimation of models with both the primary and secondary seatbelt indicators.

\section{2: Fatality Analysis Reporting System}

A limitation of the YRBS seatbelt information is that the data are all self-reported by the students. Unfortunately, we do not have a way to verify the accuracy of the self-reports directly. The concern here is that students may provide socially desirable responses to questions about risky behaviors such as (not) wearing a seatbelt, and this reporting bias may be correlated with adoption of tougher seatbelt laws (since the stigma of not wearing a seatbelt may have plausibly increased after stricter laws are put in place).

\footnotetext{
${ }^{19}$ The lone exception is Boston, Massachusetts, which we observe in 1993 but which did not adopt a seatbelt law until 1994.

${ }^{20}$ Appendix Table 1 shows the states and years represented in each of our independent YRBS samples, as well as the seatbelt laws in effect at the time of the survey.
} 
To address the possibility of this endogenous reporting bias, we perform a parallel analysis of health outcomes that are objectively measured: motor vehicle fatalities and serious nonfatal injuries resulting from fatal crashes. Specifically, we use data from the Fatality Analysis Reporting System (FARS) which contains data on a census of fatal traffic crashes within the 50 States and the District of Columbia. For each fatal accident, FARS includes information on the number of fatalities and non-fatal injuries of different severity levels that resulted from the fatal crash, as well as the date of the accident. For nonfatal injuries, we consider only the most severe injuries - those "incapacitating" injuries that prevent the injured person from "walking, driving or normally continuing the activities the person was capable of performing before the injury occurred. ${ }^{21}$ Using these data, we create counts of the number of occupant fatalities and crash-related serious injuries among high school youths aged 14-18 that occurred from fatal accidents in each state on each day from 1991 through $2005 .^{22}$ The final sample consists of fifteen years of daily fatalities for the 50 states and DC yielding a total of 279,429 state/day observations.

The basic model set up mirrors the seatbelt use analysis above. To model the count nature of the outcome variables we estimate negative binomial models on the

\footnotetext{
${ }^{21}$ Examples of such injuries include broken bones and unconsciousness. We exclude non-incapacitating injuries such as bumps and bruises, as well as injuries whose severity was unknown. Note that our sample of serious injuries is conditioned on there having been at least one fatality that resulted from the accident; as such, we must be careful not to interpret the associated estimates as the overall effect of seatbelt laws on the universe of nonfatal injuries. The purpose of examining serious nonfatal injuries is to provide additional corroborating evidence on a serious and objectively measured health outcome.

${ }^{22}$ Note that our analysis of state/day counts of fatalities is slightly different than the usual approach of aggregating up to state/year fatality counts (see, for example, Dee and Evans 2001). We examine daily fatalities to increase the precision of our seatbelt law estimates. Specifically, we know the exact date on which each state's seatbelt law went into effect. Rather than the usual approach using state/year aggregate data in which fractional values are applied to the fatalities in any state/year cell where a policy adoption occurred, our approach of using state/day counts allows us to precisely match the correct policy in place for every state/day observation. We follow the same approach in coding ZT laws, GDL policies, and .08 BAC laws. For speed limits, we use fractional values. Recall that we do not observe exact interview dates in the YRBS data, and as such we only make use of exact dates for the fatality analysis.
} 
state/day fatality counts (Cameron and Trivedi 1998). ${ }^{23}$ Specifically, we estimate models of the form:

(3) $\mathrm{Y}_{\mathrm{st}}=\beta_{0}+\beta_{1} \mathrm{X}_{\mathrm{st}}+\beta_{2}(\text { Primary Seatbelt Law })_{\mathrm{st}}+\beta_{3}(\text { Secondary Seatbelt Law })_{\mathrm{st}}+$

$$
\beta_{4} Z_{\text {st }}+\beta_{5} \text { State }+\beta_{6} \text { Year }+\varepsilon_{\text {st }}
$$

where $\mathrm{X}$ is a vector of state-specific demographic characteristics including average per capita income, the unemployment rate, and an estimate of the number of miles driven per year in each state. ${ }^{24}$ To account for exposure, $\mathrm{X}$ also includes the log of the relevant state/year population (14-18 year olds). The Primary and Secondary Seatbelt Law variables are as defined above and are matched to the exact date each relevant law became effective in the state, and we do the same matching for the state laws pertaining to motor vehicle safety and alcohol control in the $\mathrm{Z}$ vector (as described above in the seatbelt analysis). In addition to a full vector of state and year dummies, we also include dummies for: month, day of the week, Presidents' Day, St. Patrick's Day, Cinco de Mayo, Memorial Day, July $4^{\text {th }}$, Labor Day, Halloween, the day before Thanksgiving, Thanksgiving Day, Christmas Eve, Christmas Day, and New Year's Eve. As above, we cluster standard errors at the state level. Because the resulting coefficient estimates from the negative binomial model are not easily interpretable, in the tables below we present the associated marginal effects.

\section{Results}

\footnotetext{
${ }^{23}$ Although both poisson and negative binomial models are appropriate for count data, we select a negative binomial model because tests reject that the mean and variance of the dependent variable are the same, a key assumption of the poisson model.

${ }^{24}$ Vehicle miles traveled come from the 1991-2005 issues of the US Department of Transportation publication Highway Statistics.
} 
We begin with analyses of self-reported seatbelt use from the YRBS. We present descriptive statistics for the national YRBS data in Table 1a, and in Table $1 \mathrm{~b}$ we present relevant means for the local and state YRBS data. About 38 percent of youths in the national data are from state/year observations with primary enforcement seatbelt laws, while another 59 percent face secondary enforcement seatbelt laws. Only 36 percent of youths reports always wearing a seatbelt, while almost 1 in 5 reports infrequent seatbelt use. These rates of infrequent seatbelt use are extremely similar for the YRBS state surveys in the rightmost column of Table $1 \mathrm{~b}$ as well as the YRBS local surveys in the middle column of Table $1 \mathrm{~b}$. Notably, the race distribution of students from the YRBS state surveys is very similar to that of the national YRBS data, though the local YRBS surveys are largely non-white. As discussed above, nearly all youths represented in the local surveys faced some kind of mandatory seatbelt law throughout the sample period, yet fully $19.3 \%$ reported infrequent seatbelt use.

We present the distribution of actual responses to the seatbelt question from the national data in Figure 1, stratified by the type of seatbelt law in place. This picture confirms the descriptive types of evidence used in previous research on youths: seatbelt use is more common in primary enforcement states than in secondary enforcement states, which in turn is more common than in states with no seatbelt law at all. Of course, our empirical models below will rely only on the staggered timing of adoption of the seatbelt laws for identification of the policy effects. As a final piece of descriptive evidence, we present in Figure 2 the rates of infrequent seatbelt use by year from each of the three aggregated surveys (national, state, and local YRBS). Although there is some divergence 
- particularly for the state YRBS - all three show general declines in infrequent use (i.e. increases in use) over the 1993-2005 period.

We now turn to the evaluation evidence from the local, state, and national YRBS data. Table 2 presents the baseline estimates for the local (first panel) and state (second panel) YRBS analyses. Within each panel, we show results both for the full sample and for the sub-sample of state and local observations that were explicitly designed to be representative of the sampled locality in that survey year. The odd numbered columns report estimates from two-way fixed effects models with area and year fixed effects, while the even numbered columns add linear area-specific time trends. All models also include the relevant sample controls described earlier. Recall that because the local YRBS data were fielded in major cities located in states that had some type of seatbelt law by 1993, we include only the primary enforcement seatbelt law indicator in the local YRBS regressions.

The estimates in Table 2 provide consistent evidence that mandatory seatbelt laws have reduced infrequent seatbelt use by youths (i.e. they increased seatbelt use). In the differences-in-differences model using local YRBS data in Column 1, for example, primary enforcement laws are associated with a 15.5 percentage point reduction in infrequent seatbelt use, statistically significant at the five percent level. Including linear city-specific trends in Column 3 slightly increases the magnitude of the estimate suggesting a 15.9 percentage point reduction in infrequent seatbelt use. Notably, the models support the inclusion of the city trends, as they are jointly significant predictors of youth seatbelt use. Restricting attention to city/year observations that were designed to 
be representative (Columns 3-4) does not materially alter the conclusions drawn from the full sample estimates in Columns 1-2.

In the second panel of Table 2 we present the results using the state YRBS data, each time replacing city dummies and trends with state dummies and trends. Because of the wider coverage of states in these analyses, we include the secondary enforcement law variable in these models. The findings from the state YRBS analysis confirm our findings from the local YRBS analysis in the first panel: specifically, we find that a primary enforcement seatbelt law is estimated to significantly reduce infrequent seatbelt use by high school age youths by about 9.6 percentage points in Column 5, while secondary enforcement laws are estimated to reduce infrequent use by about 6.9 percentage points. Allowing for smooth linear state specific time trends increases the magnitude of these estimates (and again the trends are jointly significant determinants of youth seatbelt use in the state YRBS analyses), and the patterns do not change when we restrict attention to state/year observations with representative data. ${ }^{25}$

In Table 3 we present results from models that use the national YRBS data with state identifiers. Again, we note that these data were not designed to be state

\footnotetext{
${ }^{25}$ Recall that the estimated primary enforcement seatbelt law effect in the local YRBS models should be interpreted as the effect relative to states with a secondary enforcement law, since the cities covered in the local YRBS data had almost all been covered by a secondary enforcement law at the beginning of the sample period. The state YRBS data, however, has more extensive coverage, and as such the primary enforcement law indicator is the effect relative to states without any seatbelt law (i.e. we can credibly distinguish the effects of secondary enforcement laws in the state YRBS data). It is notable, then, that the local YRBS evaluations produce larger effects of primary enforcement laws relative to the state YRBS evaluations. Our most preferred models, for example, suggest an increase of 13.1 percentage points in the local YRBS evaluation, while the associated marginal increase for primary enforcement laws in the state analysis is $14.5-7.8=6.7$. What explains the apparent difference in the magnitude of these estimates? First, note that the difference is actually small relative to the sampling variation: the 6.4 percentage point difference is less than twice the standard error on the primary enforcement law indicator in both the local YRBS evaluation and the state YRBS evaluation. Second, it is plausible that seatbelt laws have larger effects in urban centers than in more rural areas (which are represented in the state YRBS data but not the local data), perhaps due to more visible enforcement or enhanced information dissemination. We tried to test for this directly in the fatality models below, but these models did not converge.
} 
representative, though economists have previously used the national YRBS data in evaluations such as ours (see, for example, Gruber and Zinman 2001). We present results from estimation of equation (2) in Table 3. Columns 1-2 report results for the "infrequent use" outcome (which is directly comparable to the outcome considered in Table 2), Columns 3-4 show estimates for the "always wears seatbelt" outcome, and Columns 5-6 present results for the Cohen/Einav (2003) weighted continuous seatbelt use measure. For all outcomes, we show the state and year fixed effects estimates, and the estimates that include linear state trends. ${ }^{26}$

The results in Table 3 confirm the effectiveness of primary enforcement seatbelt laws at reducing infrequent use in Columns 1-2, although we do not find evidence that secondary enforcement laws significantly reduced infrequent seatbelt use by youths. ${ }^{27}$ The point estimate in Column 2 with linear state trends suggests that primary enforcement laws reduced infrequent use by 55 percent. Across all data sources analyzed, then, primary enforcement seatbelt laws are estimated to significantly increase youth seatbelt use. Interestingly, another informative pattern also emerges from Table 3: we find quantitatively and qualitatively different results for the other measures of seatbelt use available to use in the national YRBS data. Specifically, the infrequent use outcome is the only one to return statistically significant results for the primary enforcement law variable: neither the "always" outcome nor the continuous seatbelt use outcome indicates a statistically significant effect of these strict laws, though the magnitude of the primary

\footnotetext{
${ }^{26}$ A full set of coefficient estimates is available upon request.

${ }^{27}$ The magnitudes of the estimated reductions in infrequent seatbelt use associated with mandatory seatbelt laws are smaller in the national YRBS data than in the state and local analyses. Note, however, that the standard errors for the state and local YRBS estimates are large. As such, the confidence intervals on both seatbelt law indicators for both the state and local models with area fixed effects easily include the point estimate from the national YRBS data (and vice versa).
} 
enforcement law coefficient on the continuous Cohen/Einav measure is large relative to the sample mean, implying a 43 percent effect in the model with state specific linear time trends. Overall, the patterns suggest that primary enforcement laws have their greatest effect on the extensive margin of youth seatbelt use as opposed to increasing use among users. $^{28}$

The results in Tables 2-3 provide strong evidence that state seatbelt laws particularly those mandating primary enforcement - significantly increased seatbelt use by youths. In Table 4 we provide further evidence on the unique relationship between seatbelt laws and youth seatbelt use by performing a series of falsification exercises on placebo outcomes. That is, we use the national, state, and local YRBS data to estimate parallel models of other risky youth behaviors that are similarly specified to the baseline model (i.e. models (1) and (2) above with linear area specific time trends). The outcomes we consider are: the likelihood of having had any sexual activity in the previous 3 months, the probability of having smoked cigarettes in the previous 30 days, and the probability of having consumed alcohol in the previous 30 days. $^{29}$

\footnotetext{
${ }^{28} \mathrm{We}$ also investigated whether seatbelt laws had different effects by demographic group using the race and sex information available to us in the national YRBS. These comparisons are interesting because of the well-known structural differences in belt use rates by demographic group: black and Hispanic individuals are less likely to use seatbelts, while females are more likely to use seatbelts than males. Models run separately by demographic group on the national YRBS data showed that seatbelt laws have been particularly effective at increasing belt use among minorities: primary enforcement laws reduced infrequent belt use by black and Hispanic males by 20 and 27 percentage points, respectively. For these groups, secondary enforcement laws were also effective at increasing belt use. The associated estimates for white youths are smaller and not statistically significant. The national YRBS also returned evidence that primary enforcement laws were more effective at reducing infrequent use among males than among females, though the state and local YRBS data - which report seatbelt use aggregates by sex but not by race - returned very similar estimated seatbelt law effects. FARS data do not include data on race/ethnicity consistently until 1999, and models estimated on the 1999-2005 period did not converge. We were able to estimate fatality and injury models by sex. Results generally showed larger effects for female fatality and injury reductions associated with tougher seatbelt laws, though these differences were not significant

${ }^{29}$ Our choice of placebo behavioral outcomes was driven by two concerns. First, the behaviors should have been plausibly unrelated to seatbelt laws (bicycle riding, for example, could have plausibly substituted for car riding, and as such would not have been an appropriate placebo outcome. And second, the behaviors needed to be common enough to provide us sufficient statistical power to meaningfully test the
} 
The intuition behind these exercises is straightforward: to rule out the possibility that state seatbelt laws reflect some other unobserved shock to risky behaviors among youths more generally (e.g. a state public health campaign targeted at high school age teens), we examine whether state seatbelt laws had "effects" on outcomes that should have been plausibly unaffected by the policies (or, at a minimum, these behaviors are much farther removed from the laws than seatbelt use itself). If similarly specified models returned consistent evidence that state seatbelt laws reduced several risky behaviors among youths - instead of just increasing seatbelt use - this would be evidence of omitted variables bias or some other specification error. The estimates in Table 4 which show the associated effects on the primary and secondary seatbelt law indicators in difference-in-differences models with linear trends - show that adoption of tougher state seatbelt laws was not systematically associated with changes in sexual activity, smoking, or alcohol consumption among youths. The point estimates are generally several times smaller than the associated policy effects on the infrequent seatbelt use outcome, are almost always statistically indistinguishable from zero, and exhibit no apparent pattern (i.e. seatbelt laws are about as likely to predict "good" outcomes as "bad"). These findings support the idea that mandatory seatbelt laws were uniquely effective at increasing seatbelt use among youths and provide evidence against the possibility of

relationship between seatbelt laws and the placebo outcome (marijuana use, for example, should have been plausibly unrelated to seatbelt laws but is very rare in the youth self-reports). We also considered exercise outcomes and body weight/obesity, but these questions were not consistently asked in the YRBS until 1999. For the state and local YRBS analyses, we restrict attention to the data that were designed to be representative. 
other omitted state programs or policies that were coincident with seatbelt law adoptions. $^{30}$

In Table 5 we use the national YRBS data to provide new evidence on the selective recruitment hypothesis - i.e., that individuals most likely to be involved in an accident might be the least likely to increase seatbelt use in response to a mandatory seatbelt law. This idea has been put forth by traffic safety researchers for two decades, and empirical evidence has been found for adults using seatbelt law adoptions and upgrades over the late 1980s and early 1990s. Specifically, Dee (1998) found that seatbelt laws had smaller effects on seatbelt use for drinkers and binge drinkers who have higher crash risk than other individuals. The national YRBS data, which provide information on drinking, binge drinking, and alcohol-involved driving, provide us a unique opportunity to provide a parallel analysis of selective recruitment for high school youths. We also consider past month smoking and sexual activity over the previous 3 months to assess whether youths who engage in these relatively risky behaviors are more or less responsive to mandatory seatbelt laws. ${ }^{31}$ We present these results in Table 5 for all of our seatbelt use outcomes (infrequent use, always use, and continuous use). The top row reprints the baseline estimates from our preferred models with linear state time trends from Table 3, and the successive rows restrict attention to individuals exhibiting various risky behaviors. We only report the coefficient on the primary enforcement law

\footnotetext{
${ }^{30}$ Of course, we do not wish to make too much of these falsification exercises given that we have not controlled for other determinants of these risky behaviors (sexual activity, smoking, and drinking) that previous research has shown to be important. They do, however, provide useful complementary evidence.

${ }^{31}$ Note that the null findings in Table 4 increase the validity of these comparisons across subgroups (i.e. the behaviors that define these groups were not themselves affected by mandatory seatbelt laws). Note also that this approach provides evidence against desirability bias driving our main results since these additional analyses restrict attention to youths who have already revealed a willingness to report risky and socially undesirable activity. That these youths are - as we show below - more responsive to seatbelt laws provides evidence against the idea that all of the observed increase is due to desirability/reporting bias.
} 
indicator, though each entry is from a separate regression that includes all of the control variables described earlier.

Our results in Table 5 provide evidence against selective recruitment among high school age youths. That is, we estimate that young adults who exhibit relatively risky behaviors - including those that are directly related to crash risk (drinking, binge drinking, and alcohol-involved driving) - are estimated to have larger increases in seatbelt use than the full sample. Consider the results for infrequent seatbelt use in Column 1, for example. While the full sample estimate indicates a statistically significant reduction in infrequent use of about ten percentage points, we find larger reductions of 11.7, 13.9, and 24.6 percentage points for drinkers, binge drinkers, and alcohol-involved drivers, respectively. Smokers and young adults with recent sexual behavior also show somewhat larger responsiveness on this margin. While we cannot statistically distinguish the estimates from these relatively "risky" subgroups from the baseline estimate, the patterns in Column 1 are uniformly supportive of the idea that young adults with higher crash risk were more responsive to primary enforcement seatbelt laws. We find similar patterns for continuous seatbelt use outcome in Column 3 where we find that restricting attention to the riskier subgroups returns larger coefficient estimates than the baseline that are often statistically significant. Results for "always use" in Column 2 are inconclusive. ${ }^{32}$

\footnotetext{
${ }^{32}$ These results in Table 5 also highlight the value of considering different aspects of seatbelt use. Previous research finding the strongest evidence for selective recruitment among adults came from Dee's (1998) analysis that considered the "always" seatbelt outcome. Our findings, in contrast, provide evidence against selective recruitment for different measures of belt use - infrequent use and continuous use. In addition to a different time period and different age group being studied, our analysis of other seatbelt outcomes may also account for the differences in findings.
} 
Having documented that seatbelt laws were uniquely effective at increasing selfreported seatbelt use among high school youths, we now turn to the more objectively measured outcomes available to us: highway fatalities and serious crash-related injuries from the FARS. Table 6 presents the mean descriptive statistics from the FARS over our sample period, 1991-2005. The mean traffic fatality outcome for our 14-18 year old sample is .20 measured as a state/day average or 74.2 fatalities measured as a state/year average. The associated means for nonfatal injuries are .14 and 50.5 , respectively. ${ }^{33} \mathrm{We}$ also present the mean fatality trends over our sample period separately for young adults in states with primary enforcement and secondary enforcement seatbelt laws in Figure 3. Like the seatbelt use estimates in Figure 2, we find that youth fatality rates have exhibited an overall decline since the beginning of the sample period. Consistent with a role for tougher seatbelt laws at reducing fatalities, we find that fatalities of youths living in states covered by primary enforcement seatbelt laws fell faster than fatalities of youths living in states covered by weaker secondary enforcement laws. ${ }^{34}$

We present the main fatality and injury results in Table 7. The format of Table 7 follows the seatbelt use equations from the previous tables in that for each outcome we present coefficients on the mandatory seatbelt law indicators (primary and secondary) for the difference-in-differences model with state and year fixed effects and a model that

\footnotetext{
${ }^{33}$ Note that the means of the policy variables - including the seatbelt law indicators - are slightly lower than the associated sample means from Tables $1 \mathrm{a}$ and $1 \mathrm{~b}$. This is because the analyses of fatalities and injuries use the complete balanced panel available to us from 1991-2005; that is, we observe all states in all survey years. In contrast, Appendix Tables 1 and 2 show that our coverage of states in the early part of the sample period - while extensive - is far from complete. As such, a smaller proportion of our fatality and injury observations are "covered" by the more recent traffic safety policy interventions such as primary enforcement seatbelt laws and graduated driver licensing programs. Below, we return to this issue by restricting attention to fatalities and injuries from the state/year combinations observed in our YRBS data.

${ }^{34}$ There are, of course, composition changes in the samples in Figure 3 since states are generally moving out of the secondary enforcement law group and into the primary enforcement law group. The overall trends, however, are informative.
} 
incorporates state-specific linear time trends. All models include the state demographic controls described earlier (e.g. average per capita income) as well as the other traffic safety and alcohol control laws. The table entries are marginal effects derived from the negative binomial models, which are more directly interpretable than the coefficient estimates. We present results for occupant fatalities in Columns 1-2 and for nonfatal but serious incapacitating injuries in Columns 3-4.

Results for fatalities in Columns 1-2 of Table 7 return evidence consistent with the seatbelt use results shown earlier: after accounting for state and year fixed effects, we find that adoption of primary enforcement mandatory seatbelt laws reduced highway fatalities of 14-18 year olds by .008 fatalities on an average state/day. This estimate is about a four percent effect relative to the sample mean (i.e. .008/.20) though it is not statistically significant. Allowing for linear state trends in Column 2 increases the magnitude of the coefficient estimate on the primary enforcement law indicator and suggests that such laws reduce fatalities among 14-18 year olds by about .016 - or about 8 percent of the sample mean - and this estimate is statistically significant at the one percent level. The increase in the magnitude of the effects of seatbelt laws when trends are included is consistent both with our previous seatbelt use estimates (see Tables 2 and 3 above) and with other recent fatality research suggesting downward bias from withinstate variation in youth traffic fatalities in traditional fixed effects specifications. ${ }^{35}$ Coupled with the fact that - as in the seatbelt use models - the state trends are always jointly significant in the models presented in Table 7, we consider the models with state

\footnotetext{
${ }^{35}$ Dee et al. (2005) also find that the policy effects for graduated driver licensing laws and seatbelt laws increase substantially when state trends are included in models estimated from 1992-2002. This and other evidence from their difference-in-difference-in-differences models suggest downward bias in the traditional fixed effects specifications.
} 
trends to be our preferred estimates. Notably, this model also returns evidence of a marginally significant fatality reduction associated with secondary enforcement seatbelt laws of about 4.4 percent relative to the sample mean. ${ }^{36}$ Estimates for incapacitating injuries resulting from fatal crashes in Columns 3-4 show a marginally significant reduction associated with the adoption of a primary enforcement seatbelt law among 1418 year olds by about 9 percent in the models with state time trends (i.e. .013 injury reduction relative to a sample mean of .14), with smaller and statistically insignificant effects for secondary enforcement laws. These patterns - large and significant youth health improvements for primary enforcement seatbelt laws with smaller effects for secondary laws - are consistent with the youth seatbelt use effects presented above.

We investigate the robustness of the fatality and injury effects in Table 8 . Our first robustness check addresses the possible concern that our seatbelt use estimates may not directly correspond to the fatality and injury estimates because of the differences in geographic and time coverage across the various samples (i.e. for the YRBS we are missing data from several states in various years, while we have a complete panel of fatalities and injuries for 1991-2005). To test whether the composition of the sample is contributing to the fatality and injury results, we re-estimated models on those outcomes that restricted attention to data from state/year combinations that we observe in the state YRBS data - our preferred data - as shown in Appendix Table 1. The results from this exercise are presented in Column 1 (fatalities) and Column 3 (injuries) of Table 8 . We

\footnotetext{
${ }^{36}$ A full set of coefficient estimates is available upon request. With the exception of state graduated driver licensing programs, we do not find systematic evidence that the other control variables are significantly related to fatalities of 14-18 year olds. We were able to reproduce the main result from Dee et al. (2005) that state graduated driver licensing programs mandating an intermediate driving phase were associated with significant reductions in fatalities of 15-17 year olds in models that included state and year fixed effects. When estimated on our 14-18 year old sample, we also found that the graduated driver licensing variable was consistently negative and significant.
} 
find that the estimates from the FARS subsample that most closely correspond to our seatbelt use outcomes are very similar to the baseline fatality and injury outcomes from Table 7, though not surprisingly they are much less precisely estimated with standard errors that are about two thirds larger than the baseline. ${ }^{37}$ The similarity in the magnitudes of the seatbelt law estimates from the full sample and the restricted subsample suggests that composition problems are unlikely to be seriously biasing our estimates.

We also present the results from another robustness exercise in Table 8. Recall that we depart from most previous literature by considering fatality and injury outcomes at the state/day level instead of the usual state/year aggregation. We do so to more precisely match the exact seatbelt law in place at the time of the accident instead of the usual approach of assigning fractional values to mid-year policy changes, effectively mismeasuring the policy in effect for outcomes on either side of the mid-year policy adoption in the adoption year. For purposes of comparison to the previous literature, we estimated fatality and injury models with the usual state/year aggregation and present those results in Columns 2 and 4 of Table 8 , respectively. The results from this exercise again produce evidence consistent with the idea that primary and secondary enforcement mandatory seatbelt laws significantly reduced fatalities among 14-18 year olds by about 12 and 8 percent, respectively (i.e. 8.87/74.2 and 5.91/74.2). Interestingly, these effect sizes are remarkably similar to the associated estimates of 11.7 and 10 percent from Dee et al. (2005) who employ state/year fatality aggregates over the shorter 1992-2002 period, except that our estimates are statistically significant. Estimates for injuries are similar in

\footnotetext{
${ }^{37}$ Interestingly, the estimated marginal effect for secondary enforcement law indicator is larger in the restricted subsample than in the full sample. The standard errors, however, are sufficiently large that we
} 
magnitude but are not statistically significant. Overall, the results in Columns 2 and 4 of Table 8 show that our baseline results on the effectiveness of mandatory seatbelt laws are not driven by our choice of state/day aggregation.

We conclude the results section by addressing a remaining concern with the evaluation evidence presented above. Specifically, we have not controlled for enforcement efforts and media campaigns that are designed to increase compliance with state seatbelt laws. "Click it or ticket" campaigns, for example, have been used for over a decade by states to increase awareness of new seatbelt laws, and twice a year "Buckle Up America" mobilizations occur throughout the country. These campaigns include paid media "blitzes" and increased citations by police authorities. ${ }^{38}$ And, since fiscal year 1998, states have been eligible to receive federal funding through the Transportation Equity Act for the specific purpose of increasing seatbelt use rates. If these efforts are correlated with state adoption of mandatory seatbelt laws, as is plausible, then the concern is that our seatbelt law estimates may be biased upward. ${ }^{39}$ Unfortunately, we know of no data source that systematically tracks these efforts over our time period. ${ }^{40}$

To address these types of concerns, we made use of the actual incentive grants awarded to states by the federal government for the purpose of increasing seatbelt use. The intuition is that these state grants are likely decent proxies for other unobserved efforts to increase enforcement and/or compliance. The seatbelt grant data are publicly

cannot say they are significantly different from each other.

${ }^{38}$ There are literatures on the effectiveness of these types of media campaigns, though the focus is very different from that considered here. Specifically, these interventions are "blitzes", or very short term high intensity treatments. Evaluations typically examine seatbelt use (using telephone surveys or observational studies) just before, during, and just after the campaigns. Much less research has focused on the longer term effects of the interventions, which is a distinct but very important outcome.

${ }^{39}$ Of course, our inclusion of smooth area specific trends mitigates these concerns somewhat. 
available on NHTSA's website back to 1998. We therefore observe state seatbelt grants for $1999,2001,2003$, and 2005 for the YRBS data and for 1999-2005 for the fatality data. ${ }^{41}$ We append the actual amount of grant dollars awarded (in thousands) by state/year. For those states without grant information (either because they were observed prior to 1999 or because they received no federal grant), we set the awarded grant equal to zero and include an indicator variable for observations where the federal seatbelt grant is missing. The results from this attempt to directly control for seatbelt grants are presented in Table 9 for all of the outcomes considered (seatbelt use, fatalities, and injuries). In each case, we present the coefficients on the relevant seatbelt law indicators from the difference in differences models with linear area specific time trends, and we also show the associated estimate on the actual grant award variable. ${ }^{42}$ In no case does the inclusion of seatbelt grants materially alter the main results that primary enforcement seatbelt laws increased youth seatbelt use and reduced youth fatalities and serious injuries. Moreover, estimates on the seatbelt grant variable are very small and statistically insignificant. While this approach is not ideal for capturing media campaigns and enforcement, the stability of the seatbelt law estimates suggests that the bias from their omission is not severe.

\section{Discussion and Conclusion}

The results above show that mandatory seatbelt laws adopted by states over the 19912005 period were highly effective at increasing seatbelt use and reducing fatalities and

\footnotetext{
${ }^{40}$ We attempted, for example, to obtain these data from the National Safety Council - which organizes the "Buckle Up America" program, but they indicated that this information was not tracked or readily available.

${ }^{41}$ That is, we assume that grants awarded to states in year $t$ can affect outcomes in year $t+1$.
} 
crash-related serious injuries among high school age youths (14-18). Specifically, we estimate that primary enforcement laws significantly reduce the likelihood that youths report "rarely" or "never" wearing a seatbelt by at least 8 percentage points in the national YRBS data and about 11-15 percentage points in the state and local YRBS data. Secondary enforcement laws are estimated to reduce infrequent seatbelt use by youths in the state YRBS data, though in the national data the effects are not statistically significant. With respect to the underlying mechanisms, we find the strongest and most consistent evidence that the laws increased the likelihood of any seatbelt use rather than inducing intermittent users to always buckle up. We also provide new evidence that among high school youths, those most likely to be involved in an accident show the largest increases in reported seatbelt use in response to primary enforcement laws. The self-reported seatbelt use effects were corroborated using more objectively measured data on fatalities and crash-related injuries. Similarly specified models of these health outcomes revealed that primary enforcement seatbelt laws significantly reduced fatalities of 14-18 year olds by 8 percent, with a 9 percent reduction for crash-related injuries.

It is worth comparing our results on self-reported seatbelt use to those of the only other study examining state seatbelt laws and youth seatbelt use. O'Malley and Wagenaar (2004) estimate that secondary seatbelt laws significantly increase youth seatbelt use by upwards of 70 percent. Our results, in contrast, return much more modest evidence regarding secondary enforcement laws. While there are numerous possible explanations for this discrepancy (different time periods, samples, etc.), we suspect two to be particularly relevant. First, our models include unrestricted area and year fixed effects, and we found the seatbelt law estimates to be sensitive to inclusion of these

\footnotetext{
${ }^{42}$ For the state and local YRBS analyses, we show results that restrict attention to weighted surveys.
} 
controls (i.e. the effect sizes fell when state and year dummies were included). Second, the previous study did not differentiate between laws that mandate secondary enforcement and laws that permit primary enforcement. This is important because the sample period in their study (1986-2000) witnessed 12 state adoptions of primary enforcement seatbelt laws, 8 of which were "upgrades" from previous secondary enforcement laws (see Cohen and Einav, Table 1). If these laws further increase seatbelt use rates by youths (as previous research on adults suggests and our results confirm), then failing to account for state upgrades from secondary enforcement to primary enforcement will overstate the effects of the secondary enforcement laws (since it will wrongly attribute additional increases in belt use to the secondary enforcement law that should be properly attributed to the primary enforcement law).

How important are seatbelt laws in explaining the increase in youth seatbelt use and reduction in youth fatalities over our time period? Consider that over the period 1993-2005, rates of infrequent seatbelt use fell from about 20-30 percent down to about 10 percent in all three surveys (see Figure 2). We estimate that primary enforcement seatbelt laws accounts for about 8 of the 15 percentage point decline in infrequent use in the national data, or about half of the decrease. In the state and local analyses, we estimate somewhat larger percentage point reductions in infrequent use, such that primary enforcement laws can explain about two thirds of the improvements in the state data (i.e. primary enforcement seatbelt laws account for as much as 14 of the 21 percentage point decline in infrequent seatbelt use in the state data) and essentially all the improvements in the local data. Overall, our most conservative estimates suggest that primary enforcement seatbelt laws can account for well over half of the overall improvements in 
youth seatbelt use from the early 1990 s to 2005 . With respect to fatalities, consider that the traffic fatality rate for youths aged 14-18 fell from 21.4 to 17.4 per 100,000 from the beginning to the end of our sample period. Calculations based on our estimate from column 2 of Table 7 indicate that $10.7 \%$ of this reduction was due to primary enforcement seatbelt laws.

Our results mark an important step in understanding the likely public health consequences for youths of state upgrades to primary enforcement seatbelt laws. Currently, fewer than half of all states have mandatory seatbelt laws permitting primary enforcement, and rates of infrequent use remained as high as ten percent even at the end of the sample period. Our estimates suggest that were all remaining states to upgrade their seatbelt laws to primary enforcement, regular seatbelt use by high school age youths would be nearly universal and youth fatalities would fall by around 121 per year. ${ }^{43}$

\footnotetext{
${ }^{43} 2005$ traffic fatalities of those aged 14-18 totaled 1512 in those states without primary enforcement. An $8 \%$ reduction is equal to 121 fewer deaths.
} 


\section{BIBLIOGRAPHY}

Bertrand, Marianne, Esther Duflo, and Sendhil Mullainathan (2004). "How Much Should We Trust Difference-In-Differences Estimates?," Quarterly Journal of Economics, 119(1): 249-275.

Bureau of Labor Statistics online files www.bls.gov. Accessed February 25 $5^{\text {th }}, 2007$.

Cameron, A.C. and Trivedi, P.K. 1998. Regression Analysis of Count Data. Cambridge: Cambridge University Press.

Carpenter, C. and P. Cook (2007). "The Effects of Cigarette Taxes on Youth Smoking: New Evidence from National, State, and Local Youth Risk Behavior Surveys," Journal of Health Economics, forthcoming.

Cohen, A. and L. Einav (2003). "The Effects of Mandatory Seat Belt Laws on Driving Behavior and Traffic Fatalities," Review of Economics and Statistics, 85(4): 828843.

Dee, T. (1998). "Reconsidering the Effects of Seat Belt Laws and Their Enforcement Status," Accident Analysis and Prevention, 30(1): 1-10.

Dee, T. and W. N. Evans (2001a). "Behavioral Policies and Teen Traffic Safety," American Economic Review, 91(2): 91-96.

--- (2001b). "Teens and Traffic Safety," in Risky Behavior Among Youths: An Economic Analysis, J. Gruber, Ed. Chicago, University of Chicago Press.

Dee, T., D. Grabowksi, and M. Morrisey (2005). "Graduated driver licensing and teen traffic fatalities," Journal of Health Economics, 24(3): 571-589.

Eisenberg, D. (2001). "Evaluating the Effectiveness of Policies Related to Drunk Driving," Journal of Policy Analysis and Management, 22(2): 249-274.

Evans, W. and J. Graham (1991). "Risk reduction or risk compensation? The case of mandatory safety-belt use laws," Journal of Risk and Uncertainty, 4: 61-73.

Gruber, J. and J. Zinman (2001). "Youth Smoking in the United States: Evidence and Implications," in Risky Behavior Among Youths: An Economic Analysis, J. Gruber, Ed. Chicago, University of Chicago Press.

Hedlund, J. and R. Compton (2005). "Graduated Driver Licensing Research in 2004 and 2005,” Journal of Safety Research, 36: 4-14.

Houston D. and L. Richardson (2006). "Reducing Traffic Fatalities in the American States by Upgrading Seat Belt Use Laws to Primary Enforcement," Journal of Policy Analysis and Management, 25(3): 645-659. 
--- (2005). "Getting Americans to buckle up: The efficacy of state seat belt laws," Accident Analysis and Prevention, 37: 1114-1120.

McCartt, A., and V. Shabanova (2002). "Teenage Seat Belt Use: White Paper." The National Safety Council’s Air Bag \& Seat Belt Safety Campaign.

Morrisey M., D. Grabowski, T. Dee and C. Campbell (2006). "The Strength of Graduated Drivers License Programs and Fatalities Among Teen Drivers and Passengers," Accident Analysis and Prevention, 38:135-141.

National Highway Traffic Safety Administration (NHTSA) (2003). "Safety Belts and Teens 2003 Report". Available online at http://www.nhtsa.dot.gov/people/injury/airbags/buasbteens03/index.htm.

O'Malley, P. and A. Wagenaar (2004). "Effects of safety belt laws on safety belt use by American High School Seniors, 1986-2000," Journal of Safety Research, 35: 125130.

Sen, A. (2006). "Estimating the Impact of Seat Belt Use on Traffic Fatalities: Empirical Evidence from Canada," working paper.

--- (2001). "Do stricter penalties deter drinking and driving? An empirical investigation of Canadian impaired driving laws," Canadian Journal of Economics, 34(1): 149164.

U.S. Department of Transportation (1990-2005). Highway Statistics, Federal Highway Administration, Office of Highway Policy Information.

Williams, A., A. McCartt, and L. Geary (2003). "Seat belt use by high school students," Injury Prevention, 9: 25-28.

Womack, K., N. Trout, and B. Davis (1997). "Characteristics and Conditions of Teenage Safety Belt Use.” Report No. DOT HS-808-676. Washington, DC. National Highway Transportation Safety Administration. 


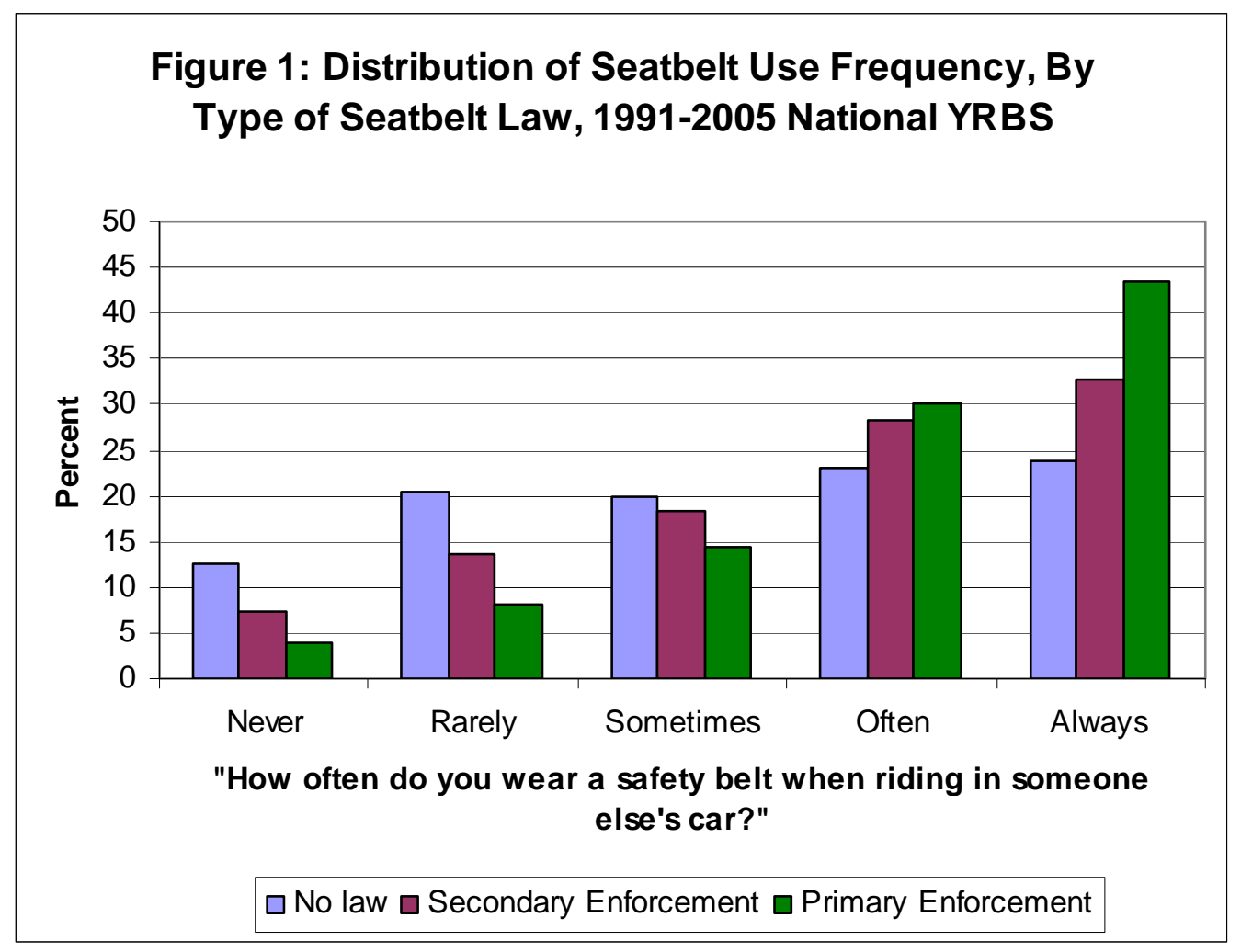


Figure 2: Percent Infrequent Seatbelt Use Among High School Age Youths, 1991-2005 National, State, and Local YRBS

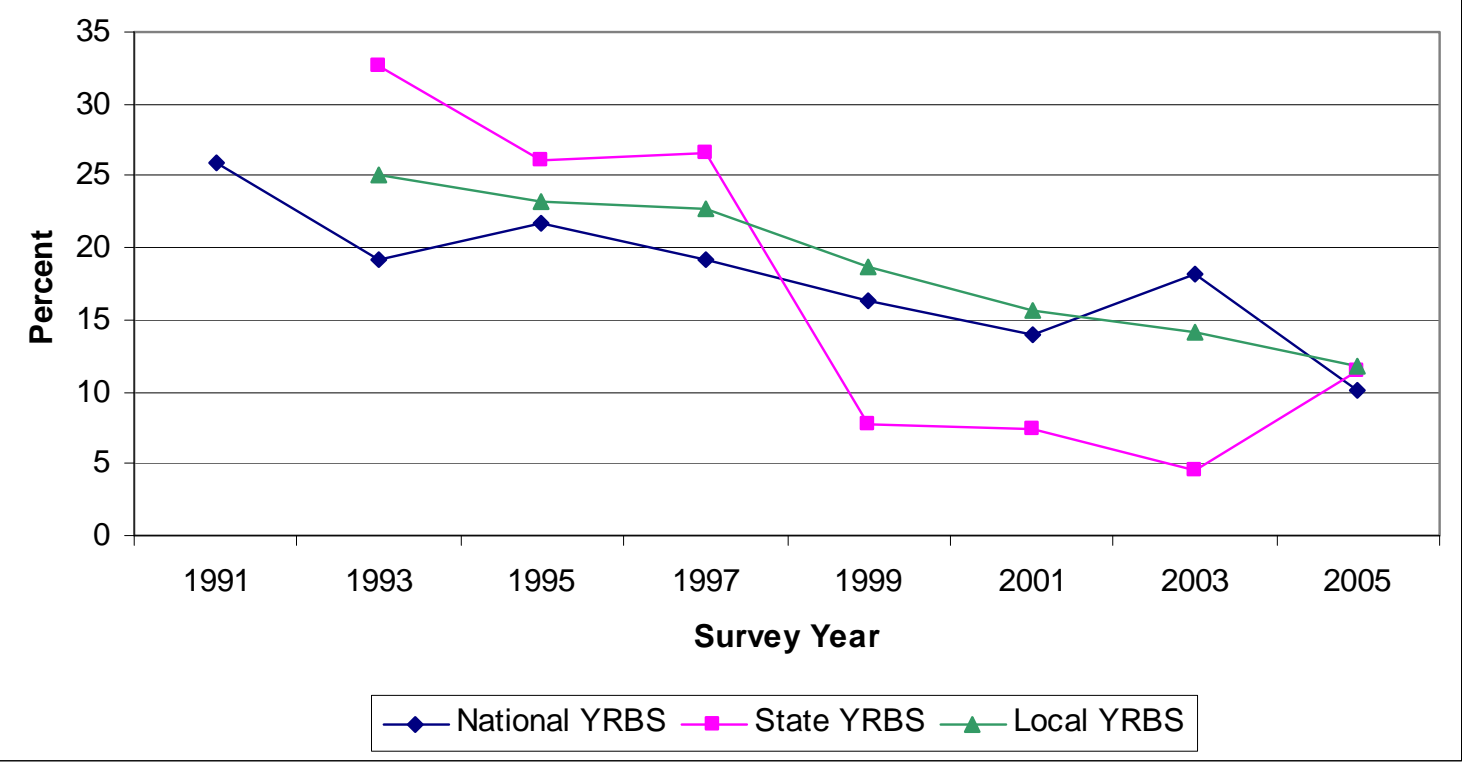




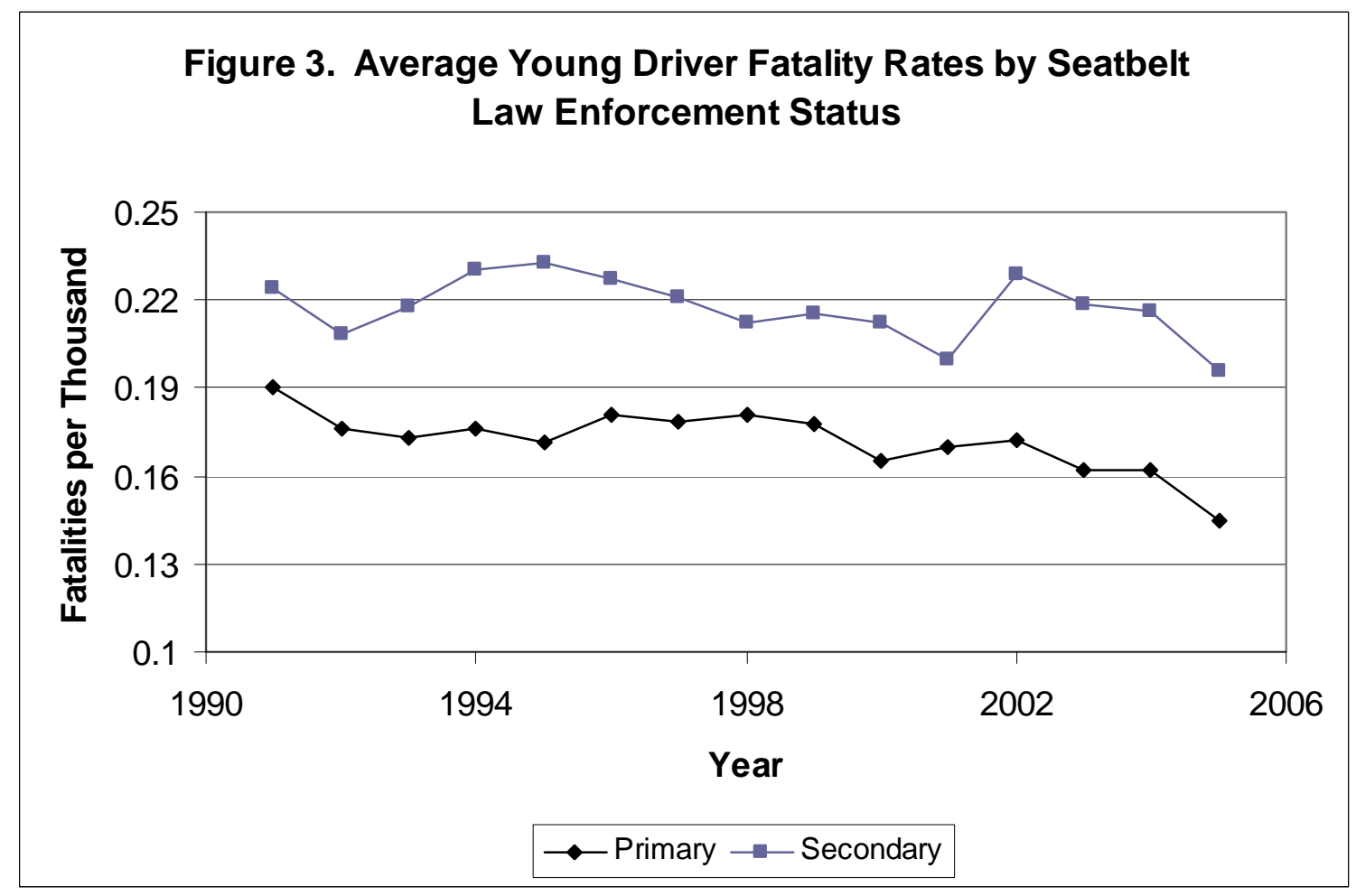


Table 1a:

Descriptive Statistics

1991-2005 National Youth Risk Behavior Surveys

Age

Black race

Other race

Hispanic

Female

Primary enforcement seatbelt law

Secondary enforcement seatbelt law

Any GDL program with intermediate phase

.08 BAC law

Zero Tolerance law

$65 \mathrm{mph}$ speed limit

$70+$ mph speed limit

Always wears seatbelt

Never/rarely wears seatbelt (infrequent use)

16.1

.14

.10

.11

.49

.38

.58

.42

.44

.70

.54

.40

.36

.18

National YRBS data are weighted means.

Table 1b:

Descriptive Statistics

1993-2005 Local and State Youth Risk Behavior Surveys

\begin{tabular}{lcc}
\hline & YRBS Local & YRBS State Surveys \\
Percent from representative surveys & .88 & .79 \\
Of the representative surveys: & & \\
Overall response rate & 72.8 & 68.7 \\
School response rate & 97.8 & 85.1 \\
Student response rate & 74.4 & 80.9 \\
Percent female & 50.6 & 49.4 \\
Percent grade 9 & 33.7 & 28.9 \\
Percent grade 10 & 26.3 & 25.6 \\
Percent grade 11 & 21.3 & 23.3 \\
Percent grade 12 & 18.4 & 21.5 \\
Percent white & 19.5 & 68.3 \\
& & \\
Primary enforcement seatbelt law & .46 & .26 \\
Secondary enforcement seatbelt law & .53 & .65 \\
Any GDL program & .62 & .42 \\
.08 BAC law & .57 & .44 \\
Zero Tolerance law & .82 & .74 \\
65 mph speed limit & .41 & .48 \\
70+ mph speed limit & .55 & .45 \\
& & \\
Percent infrequent seatbelt use & 19.3 & 18.5 \\
\hline State and Locl YRBS
\end{tabular}

State and Local YRBS means are unweighted. 
Table 2:

Mandatory Seatbelt Laws and Infrequent Seatbelt Use - Local and State YRBS Data 1993-2005

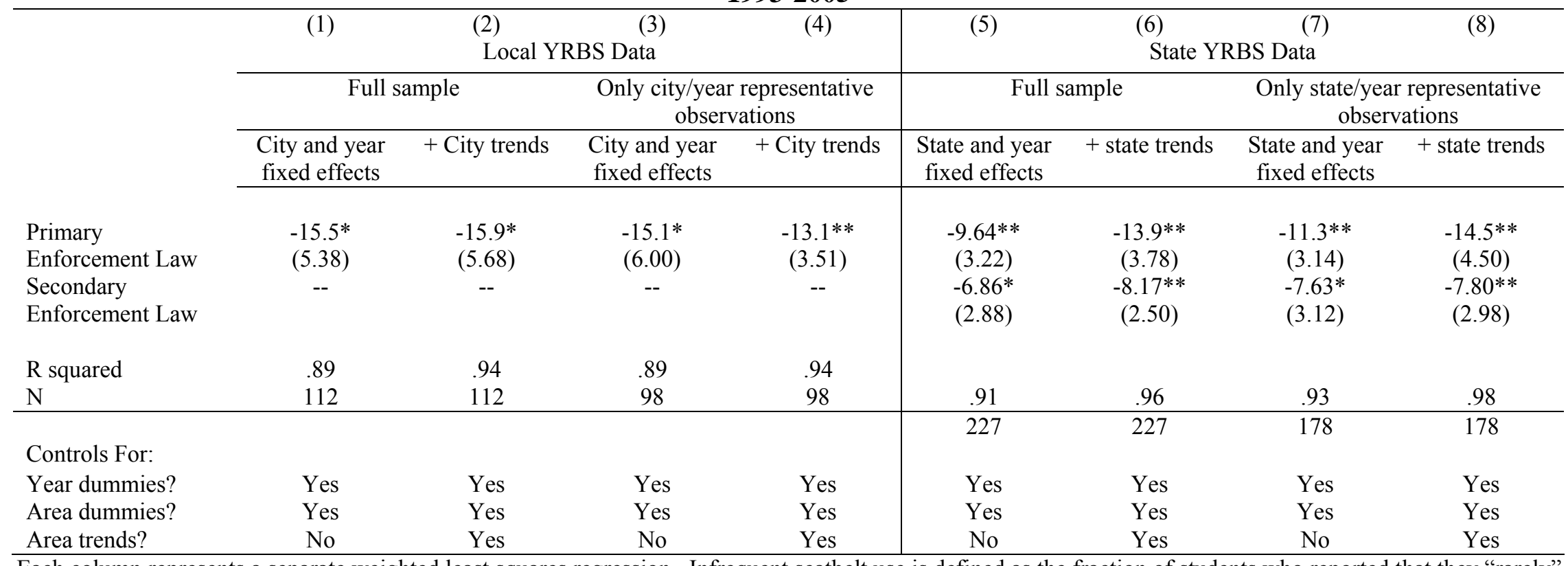

Each column represents a separate weighted least squares regression. Infrequent seatbelt use is defined as the fraction of students who reported that they "rarely" or "never" wear a seatbelt when riding in someone else's car. Models also include controls for: the state unemployment rate, an indicator for the presence of a .08 BAC law, a Zero Tolerance law, a graduated driver licensing law, speed limits (65mph and 70mph+), overall survey response rate, student response rate, school response rate, percent female, percent black, percent Hispanic, percent other race, percent grade 10, percent grade 11, and percent grade 12 . $†$ significant at $10 \% ; *$ significant at $5 \% ; * *$ significant at $1 \%$. In all cases, robust standard errors are clustered at the state level. 
Table 3:

Mandatory Seatbelt Laws and Alternative Measures of Youth Seatbelt Use - National YRBS Data

1991-2005

\begin{tabular}{|c|c|c|c|c|c|c|}
\hline & (1) & (2) & (3) & (4) & (5) & (6) \\
\hline & $\begin{array}{l}\text { State and year } \\
\text { fixed effects }\end{array}$ & + state trends & $\begin{array}{l}\text { State and year } \\
\text { fixed effects }\end{array}$ & + state trends & $\begin{array}{l}\text { State and year } \\
\text { fixed effects }\end{array}$ & + state trends \\
\hline & \multicolumn{2}{|c|}{$\begin{array}{l}\text { Infrequent Seatbelt Use, Probit } \\
\text { Sample mean }=.18\end{array}$} & \multicolumn{2}{|c|}{$\begin{array}{l}\text { Always Wears Seatbelt, Probit } \\
\text { Sample mean }=.36\end{array}$} & \multicolumn{2}{|c|}{$\begin{array}{c}\text { Cohen \& Einav Continuous Belt Use, } \\
\text { OLS } \\
\text { Sample mean }=.64\end{array}$} \\
\hline Primary Enforcement Law & $\begin{array}{l}-.084^{\dagger} \\
(.042)\end{array}$ & $\begin{array}{c}-.099 * * \\
(.034)\end{array}$ & $\begin{array}{l}.051 \\
(.062)\end{array}$ & $\begin{array}{l}-.009 \\
(.061)\end{array}$ & $\begin{array}{l}.316 \\
(.222)\end{array}$ & $\begin{array}{c}.277 \\
(.193)\end{array}$ \\
\hline $\begin{array}{l}\text { Secondary Enforcement } \\
\text { Law }\end{array}$ & $\begin{array}{l}-.028 \\
(.013)\end{array}$ & $\begin{array}{l}-.050 \\
(.031)\end{array}$ & $\begin{array}{l}-.004 \\
(.067)\end{array}$ & $\begin{array}{l}-.054 \\
(.056)\end{array}$ & $\begin{array}{l}.107 \\
(.250)\end{array}$ & $\begin{array}{l}.092 \\
(.173)\end{array}$ \\
\hline $\mathrm{R}$ squared & .07 & .08 & .05 & .06 & .11 & .12 \\
\hline $\mathrm{N}$ & 112864 & 112864 & 112864 & 112864 & 112864 & 112864 \\
\hline \multicolumn{7}{|l|}{ Controls For: } \\
\hline Year dummies? & Yes & Yes & Yes & Yes & Yes & Yes \\
\hline State dummies? & Yes & Yes & Yes & Yes & Yes & Yes \\
\hline State trends? & No & Yes & No & Yes & No & Yes \\
\hline
\end{tabular}


Table 4:

Falsification Exercises on Placebo Outcomes

1991-2005 National, State, and Local YRBS

\begin{tabular}{|c|c|c|c|c|c|c|c|c|c|}
\hline & (1) & (2) & (3) & (4) & $(5)$ & (6) & (7) & (8) & (9) \\
\hline & $\begin{array}{c}\text { Any sex - } \\
\text { past } 3 \\
\text { months }\end{array}$ & $\begin{array}{c}\text { Past } 30 \text { day } \\
\text { smoker }\end{array}$ & $\begin{array}{c}\text { Past } 30 \text { day } \\
\text { drinker }\end{array}$ & $\begin{array}{c}\text { Any sex - } \\
\text { past } 3 \\
\text { months }\end{array}$ & $\begin{array}{c}\text { Past } 30 \text { day } \\
\text { smoker }\end{array}$ & $\begin{array}{c}\text { Past } 30 \text { day } \\
\text { drinker }\end{array}$ & $\begin{array}{c}\text { Any sex - } \\
\text { past } 3 \\
\text { months }\end{array}$ & $\begin{array}{c}\text { Past } 30 \text { day } \\
\text { smoker }\end{array}$ & $\begin{array}{c}\text { Past } 30 \text { day } \\
\text { drinker }\end{array}$ \\
\hline & National & National & National & State & State & State & Local & Local & Local \\
\hline Sample mean: & .33 & .29 & .46 & 35.1 & 27.9 & 45.8 & 36.9 & 18.7 & 39.4 \\
\hline Primary & .021 & .011 & .057 & 1.06 & .789 & 4.83 & -1.99 & -1.51 & -1.07 \\
\hline Enforcement Law & $(.053)$ & $(.028)$ & $(.038)$ & $(3.44)$ & $(2.23)$ & $(6.25)$ & $(2.43)$ & (3.17) & $(2.11)$ \\
\hline Secondary & -.012 & $.043^{*}$ & .045 & -.393 & .859 & 6.45 & -- & -- & -- \\
\hline Enforcement Law & $(.037)$ & $(.021)$ & $(.033)$ & $(2.53)$ & $(1.53)$ & $(6.57)$ & & & \\
\hline R squared & .07 & .05 & .03 & .98 & .98 & .89 & .97 & .98 & .95 \\
\hline $\mathrm{N}$ & 112407 & 112864 & 112864 & 158 & 181 & 181 & 96 & 97 & 97 \\
\hline \multicolumn{10}{|l|}{ Controls For: } \\
\hline Year dummies? & Yes & Yes & Yes & Yes & Yes & Yes & Yes & Yes & Yes \\
\hline Area dummies? & Yes & Yes & Yes & Yes & Yes & Yes & Yes & Yes & Yes \\
\hline Area trends? & Yes & Yes & Yes & Yes & Yes & Yes & Yes & Yes & Yes \\
\hline
\end{tabular}


Table 5:

\section{Evidence on Selective Recruitment \\ Coefficients on Primary Enforcement Seatbelt Law Indicator 1991-2005 National YRBS}

\begin{tabular}{|c|c|c|c|c|}
\hline & (1) & (2) & (3) & (4) \\
\hline & $\begin{array}{l}\text { Infrequent } \\
\text { seatbelt use }\end{array}$ & $\begin{array}{c}\text { Always wears } \\
\text { seatbelt }\end{array}$ & $\begin{array}{l}\text { Continuous } \\
\text { seatbelt use }\end{array}$ & $\begin{array}{c}\text { Number of } \\
\text { observations }\end{array}$ \\
\hline Baseline (full sample) & $\begin{array}{c}-.099 * * \\
(.034)\end{array}$ & $\begin{array}{l}-.009 \\
(.061)\end{array}$ & $\begin{array}{l}.277 \\
(.193)\end{array}$ & 112864 \\
\hline Past month drinkers & $\begin{array}{l}-.117 * \\
(.043)\end{array}$ & $\begin{array}{l}.017 \\
(.055)\end{array}$ & $\begin{array}{l}.343^{\dagger} \\
(.189)\end{array}$ & 50662 \\
\hline Past month binge drinkers & $\begin{array}{l}-.139 * \\
(.062)\end{array}$ & $\begin{array}{l}.073 \\
(.064)\end{array}$ & $\begin{array}{l}.485^{*} \\
(.230)\end{array}$ & 31086 \\
\hline Past month alcohol-involved drivers & $\begin{array}{l}-.246^{\dagger} \\
(.121)\end{array}$ & $\begin{array}{l}-.017 \\
(.099)\end{array}$ & $\begin{array}{c}.513 \\
(.411)\end{array}$ & 15203 \\
\hline Past month smokers & $\begin{array}{c}-.104^{\dagger} \\
(.058)\end{array}$ & $\begin{array}{c}.038 \\
(.066)\end{array}$ & $\begin{array}{c}.368^{\dagger} \\
(.202)\end{array}$ & 29299 \\
\hline Had sexual activity in past 3 months & $\begin{array}{l}-.132^{*} \\
(.032)\end{array}$ & $\begin{array}{l}-.028 \\
(.081)\end{array}$ & $\begin{array}{l}.303 \\
(.259)\end{array}$ & 41613 \\
\hline
\end{tabular}


Table 6:

Descriptive Statistics

1991-2005 Fatality Analysis Reporting System (FARS)

Traffic fatalities, age 14-18

74.2

Traffic fatalities, age 14-18 (state/day average)

.20

Incapacitating nonfatal crash-related injuries, age 14-18

50.5

Incapacitating nonfatal crash-related injuries, age 14-18

.14

(state/day average)

Primary enforcement seatbelt law

.28

Secondary enforcement seatbelt law

.66

Any GDL program with intermediate phase

.08 BAC law

.40

Zero Tolerance law

.69

$65 \mathrm{mph}$ speed limit

.54

$70+$ mph speed limit

.34

Sample means are state/year averages (except where noted) for the 50 states and the District of Columbia. 
Table 7:

Mandatory Seatbelt Laws, Traffic Fatalities, and Crash-Related Injuries

FARS 1991-2005

(1) (2)

Occupant fatalities

State and year $\quad+$ state trends

fixed effects

\begin{tabular}{lcccc} 
Primary Enforcement & -.007 & $-.016^{* *}$ & -.002 & $-.013^{\dagger}$ \\
Law & $(.006)$ & $(.006)$ & $(.008)$ & $(.007)$ \\
Secondary Enforcement & .004 & $-.009^{\dagger}$ & .007 & -.007 \\
Law & $(.004)$ & $(.005)$ & $(.007)$ & \\
& & & & \\
& & & & \\
$\mathrm{N}$ & 279429 & 279429 & 279429 & 279429 \\
\hline & & & & \\
Controls For: & & & Yes & Yes \\
Year dummies? & Yes & Yes & Yes & Yes \\
State dummies? & Yes & Yes & No & Yes \\
State trends? & No & Yes & No
\end{tabular}

Each column represents a separate negative binomial regression estimated on the state/day count of fatalities (Columns 1-2) or injuries (Columns 3-4) of youths age 14-18. We present marginal effects and associated standard errors clustered at the state level. Models also include controls for: the state unemployment rate, an indicator for the presence of a $.08 \mathrm{BAC}$ law, a Zero Tolerance law, a graduated driver licensing law, and speed limits $(65 \mathrm{mph}, 70+\mathrm{mph})$. $\dagger$ significant at $10 \%$; $*$ significant at $5 \%$; ** significant at $1 \%$. 


\section{Table 8:}

\section{Robustness Analyses: Fatalities and Injuries}

FARS 1991-2005

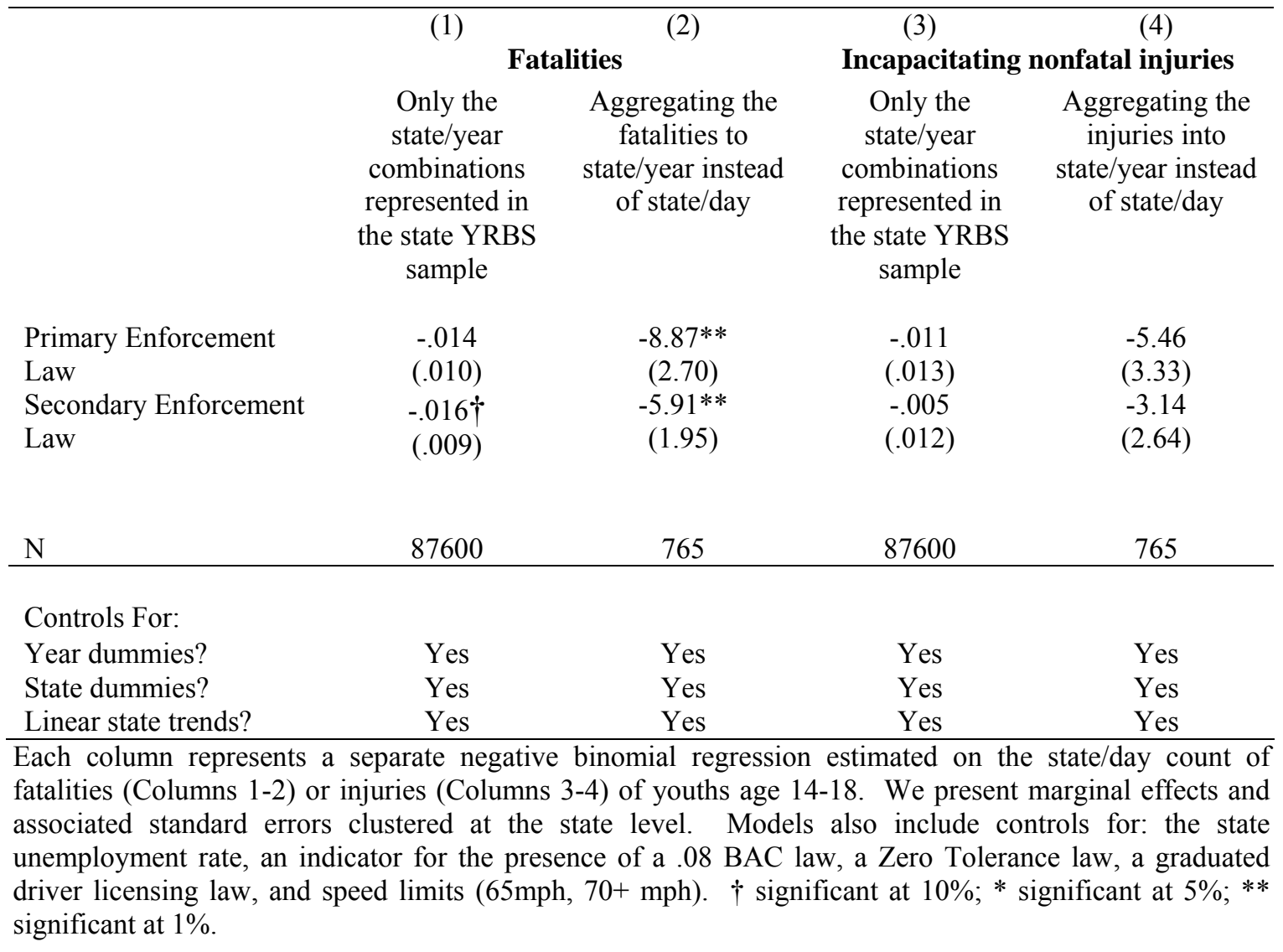




\section{Table 9:}

Addressing Concerns About Enforcement \& Media Campaigns 1991-2005 National, State, and Local YRBS

\begin{tabular}{|c|c|c|c|c|c|}
\hline & $\begin{array}{c}\text { (1) } \\
\text { Infrequent } \\
\text { Seatbelt Use } \\
\text { National } \\
\text { YRBS }\end{array}$ & $\begin{array}{c}(2) \\
\text { Infrequent } \\
\text { Seatbelt Use } \\
\text { State YRBS }\end{array}$ & $\begin{array}{c}(3) \\
\text { Infrequent } \\
\text { Seatbelt Use } \\
\text { Local YRBS }\end{array}$ & $\begin{array}{c}\text { (4) } \\
\text { Fatalities } \\
\text { FARS }\end{array}$ & $\begin{array}{c}\text { (5) } \\
\text { Injuries } \\
\text { FARS }\end{array}$ \\
\hline $\begin{array}{l}\text { Primary } \\
\text { Enforcement Law } \\
\text { Secondary } \\
\text { Enforcement Law }\end{array}$ & $\begin{array}{l}-.099 * * \\
(.035) \\
-.050 \\
(.032)\end{array}$ & $\begin{array}{c}-14.5^{* *} \\
(4.61) \\
-7.82^{*} \\
(2.95)\end{array}$ & $\begin{array}{c}-13.2^{* *} \\
(3.78) \\
--\end{array}$ & $\begin{array}{c}-.016^{* *} \\
(.006) \\
-.008^{\dagger} \\
(.005)\end{array}$ & $\begin{array}{l}-.013 \dagger \\
(.007) \\
-.007 \\
(.007)\end{array}$ \\
\hline $\begin{array}{l}\text { Seatbelt grant } \\
(\mathrm{x} 1000)\end{array}$ & $\begin{array}{l}.000 \\
(.000)\end{array}$ & $\begin{array}{l}-.0001 \\
(.003)\end{array}$ & $\begin{array}{l}.001 \\
(.003)\end{array}$ & $\begin{array}{l}-.001 \\
(.000)\end{array}$ & $\begin{array}{l}.001 \\
(.001)\end{array}$ \\
\hline $\mathrm{N}$ & 112864 & 178 & 98 & 279429 & 279429 \\
\hline $\begin{array}{l}\text { Controls For: } \\
\text { Year dummies? } \\
\text { Area dummies? } \\
\text { Area trends? }\end{array}$ & $\begin{array}{l}\text { Yes } \\
\text { Yes } \\
\text { Yes }\end{array}$ & $\begin{array}{l}\text { Yes } \\
\text { Yes } \\
\text { Yes }\end{array}$ & $\begin{array}{l}\text { Yes } \\
\text { Yes } \\
\text { Yes }\end{array}$ & $\begin{array}{l}\text { Yes } \\
\text { Yes } \\
\text { Yes }\end{array}$ & $\begin{array}{l}\text { Yes } \\
\text { Yes } \\
\text { Yes }\end{array}$ \\
\hline
\end{tabular}


Appendix Table 1:

$\mathrm{N}$ indicates national YRBS data for that state in that year

$S$ indicates state YRBS data for that state in that year

$L$ indicates local YRBS data for at least one locality in that state in that year

Primary Seatbelt law indicated by dark shaded area

Secondary seatbelt law indicated by light shaded area

\begin{tabular}{|c|c|c|c|c|c|c|c|c|}
\hline Location & 1991 & 1993 & 1995 & 1997 & 1999 & 2001 & 2003 & 2005 \\
\hline Alabama & & NS & $\mathrm{NS}$ & NS & NS & NS & NS & $\mathrm{S}$ \\
\hline Alaska & & & $\mathrm{S}$ & & $\mathrm{S}$ & & $\mathrm{S}$ & \\
\hline Arizona & & $\mathrm{N}$ & & $\mathrm{N}$ & $\mathrm{N}$ & $\mathrm{N}$ & NS & NS \\
\hline Arkansas & & NS & NS & NS & $\mathrm{S}$ & $\mathrm{S}$ & $\mathrm{N}$ & $\mathrm{S}$ \\
\hline California & $\mathrm{N}$ & NL & NSL & NSL & NL & $\mathrm{NL}$ & NL & NL \\
\hline Colorado & $\mathrm{N}$ & $\mathrm{N}$ & NSL & NS & & NS & & $\mathrm{S}$ \\
\hline Connecticut & & & & NS & $\mathrm{S}$ & & & NS \\
\hline Delaware & & $\mathrm{S}$ & NS & $\mathrm{S}$ & $\mathrm{S}$ & $\mathrm{S}$ & NS & $\mathrm{S}$ \\
\hline $\mathrm{DC}$ & & $\mathrm{S}$ & NS & $\mathrm{S}$ & $\mathrm{S}$ & $\mathrm{S}$ & $\mathrm{S}$ & $\mathrm{S}$ \\
\hline Florida & $\mathrm{N}$ & $\mathrm{NL}$ & $\mathrm{NL}$ & NSL & NSL & NSL & NSL & NSL \\
\hline Georgia & $\mathrm{N}$ & NS & NS & $\mathrm{N}$ & $\mathrm{N}$ & $\mathrm{N}$ & NS & NSL \\
\hline Hawaii & & $\mathrm{S}$ & $\mathrm{S}$ & $\mathrm{S}$ & NS & $\mathrm{S}$ & & $\mathrm{S}$ \\
\hline Idaho & & $\mathrm{S}$ & $\mathrm{S}$ & & & NS & $\mathrm{S}$ & $\mathrm{N}$ \\
\hline Illinois & $\mathrm{N}$ & NSL & NSL & $\mathrm{L}$ & NSL & NSL & $\mathrm{NL}$ & NL \\
\hline Indiana & $\mathrm{N}$ & & & & & NS & NS & NS \\
\hline Iowa & & & $\mathrm{N}$ & NS & $\mathrm{S}$ & $\mathrm{S}$ & & NS \\
\hline Kansas & & $\mathrm{N}$ & & $\mathrm{N}$ & & & $\mathrm{N}$ & NS \\
\hline Kentucky & & $\mathrm{S}$ & & $\mathrm{S}$ & $\mathrm{S}$ & $\mathrm{S}$ & $\mathrm{S}$ & NS \\
\hline Louisiana & & SL & NL & NSL & NSL & SL & NL & NL \\
\hline Maine & & NS & NS & NS & NS & NS & NS & $\mathrm{S}$ \\
\hline Maryland & $\mathrm{N}$ & $\mathrm{N}$ & & NL & & & $\mathrm{N}$ & SL \\
\hline Massachusetts & & NSL & NSL & NSL & SL & NSL & NSL & NSL \\
\hline Michigan & $\mathrm{N}$ & $\mathrm{N}$ & NSL & NSL & NSL & NSL & NSL & NSL \\
\hline Minnesota & & $\mathrm{N}$ & & & & & & $\mathrm{N}$ \\
\hline Mississippi & $\mathrm{N}$ & NS & NS & NS & NS & NS & $\mathrm{S}$ & $\mathrm{S}$ \\
\hline Missouri & $\mathrm{N}$ & $\mathrm{N}$ & NS & $\mathrm{S}$ & NS & NS & NS & NS \\
\hline Montana & & $\mathrm{S}$ & $\mathrm{S}$ & $\mathrm{S}$ & $\mathrm{S}$ & NS & $\mathrm{S}$ & $\mathrm{S}$ \\
\hline Nebraska & & NS & $\mathrm{S}$ & & $\mathrm{S}$ & $\mathrm{S}$ & $\mathrm{S}$ & $\mathrm{S}$ \\
\hline Nevada & & $\mathrm{S}$ & $\mathrm{S}$ & $\mathrm{S}$ & $\mathrm{S}$ & NS & $\mathrm{S}$ & $\mathrm{S}$ \\
\hline NewHampshire & $\mathrm{N}$ & $\mathrm{S}$ & $\mathrm{S}$ & $\mathrm{S}$ & $\mathrm{S}$ & $\mathrm{S}$ & $\mathrm{S}$ & $\mathrm{S}$ \\
\hline New Jersey & $\mathrm{N}$ & SL & SL & NSL & NS & NS & $\mathrm{N}$ & NS \\
\hline New Mexico & $\mathrm{N}$ & NS & & $\mathrm{N}$ & $\mathrm{S}$ & $\mathrm{N}$ & $\mathrm{N}$ & $\mathrm{S}$ \\
\hline New York & $\mathrm{N}$ & NSL & $\mathrm{N}$ & NSL & NSL & NSL & NS & NSL \\
\hline North Carolina & & NS & NS & NS & $\mathrm{N}$ & NS & $\mathrm{S}$ & NSL \\
\hline North Dakota & & & $\mathrm{S}$ & $\mathrm{S}$ & $\mathrm{S}$ & $\mathrm{S}$ & $\mathrm{S}$ & $\mathrm{S}$ \\
\hline Ohio & $\mathrm{N}$ & NS & NS & NS & NS & $\mathrm{N}$ & NS & NS \\
\hline Oklahoma & & & & $\mathrm{N}$ & & $\mathrm{N}$ & $\mathrm{S}$ & NS \\
\hline Oregon & & NS & & & & $\mathrm{N}$ & & $\mathrm{N}$ \\
\hline Pennsylvania & $\mathrm{N}$ & NL & NL & NL & $\mathrm{NL}$ & $\mathrm{L}$ & NL & NL \\
\hline Rhode Island & & & $\mathrm{S}$ & $\mathrm{S}$ & $\mathrm{N}$ & $\mathrm{S}$ & $\mathrm{S}$ & $\mathrm{S}$ \\
\hline
\end{tabular}




\begin{tabular}{|l|c|c|c|c|c|c|c|c|}
\hline South Carolina & $\mathrm{N}$ & $\mathrm{NS}$ & $\mathrm{S}$ & $\mathrm{NS}$ & $\mathrm{S}$ & $\mathrm{NS}$ & $\mathrm{N}$ & NS \\
\hline South Dakota & $\mathrm{N}$ & $\mathrm{S}$ & $\mathrm{S}$ & $\mathrm{S}$ & $\mathrm{S}$ & $\mathrm{S}$ & $\mathrm{NS}$ & $\mathrm{S}$ \\
\hline Tennessee & & $\mathrm{NS}$ & $\mathrm{NS}$ & $\mathrm{NS}$ & $\mathrm{NS}$ & $\mathrm{NS}$ & $\mathrm{SL}$ & $\mathrm{NSL}$ \\
\hline Texas & $\mathrm{N}$ & $\mathrm{NL}$ & $\mathrm{NL}$ & $\mathrm{NL}$ & $\mathrm{NL}$ & $\mathrm{NSL}$ & $\mathrm{NSL}$ & $\mathrm{NSL}$ \\
\hline Utah & & $\mathrm{S}$ & $\mathrm{S}$ & $\mathrm{S}$ & $\mathrm{S}$ & $\mathrm{S}$ & $\mathrm{NS}$ & $\mathrm{NS}$ \\
\hline Vermont & $\mathrm{N}$ & $\mathrm{S}$ & $\mathrm{S}$ & $\mathrm{S}$ & $\mathrm{S}$ & $\mathrm{S}$ & $\mathrm{NS}$ & $\mathrm{S}$ \\
\hline Virginia & $\mathrm{N}$ & & $\mathrm{N}$ & & $\mathrm{N}$ & & $\mathrm{N}$ & $\mathrm{N}$ \\
\hline Washington & $\mathrm{N}$ & $\mathrm{NL}$ & $\mathrm{NL}$ & $\mathrm{N}$ & $\mathrm{L}$ & $\mathrm{N}$ & & $\mathrm{N}$ \\
\hline West Virginia & & $\mathrm{NS}$ & $\mathrm{S}$ & $\mathrm{S}$ & $\mathrm{S}$ & $\mathrm{N}$ & $\mathrm{S}$ & $\mathrm{NS}$ \\
\hline Wisconsin & & $\mathrm{S}$ & & $\mathrm{NS}$ & $\mathrm{NS}$ & $\mathrm{NSL}$ & $\mathrm{NSL}$ & $\mathrm{NSL}$ \\
\hline Wyoming & & $\mathrm{S}$ & $\mathrm{S}$ & $\mathrm{S}$ & $\mathrm{S}$ & $\mathrm{S}$ & $\mathrm{S}$ & $\mathrm{S}$ \\
\hline
\end{tabular}


Appendix Table 2:

Cities participating in the Local YRBS

Primary Seatbelt law indicated by dark shaded area

Secondary seatbelt law indicated by light shaded area

\begin{tabular}{|c|c|c|c|c|c|c|c|}
\hline Location & 1993 & 1995 & 1997 & 1999 & 2001 & 2003 & 2005 \\
\hline Los Angeles, CA & & $\mathrm{X}$ & $\mathrm{X}$ & & $\bar{X}$ & $\mathrm{X}$ & \\
\hline San Bernardino, CA & & & & $\mathrm{X}$ & $\bar{X}$ & $\mathrm{X}$ & $\bar{X}$ \\
\hline San Diego, CA & $\mathrm{X}$ & $\mathrm{X}$ & $\mathrm{X}$ & $\mathrm{X}$ & $\mathrm{X}$ & $\mathrm{X}$ & $\mathrm{X}$ \\
\hline San Francisco, CA & $\mathrm{X}$ & $\mathrm{X}$ & $\mathrm{X}$ & $\mathrm{X}$ & $\mathrm{X}$ & & $\mathrm{X}$ \\
\hline Denver, $\mathrm{CO}$ & & $\mathrm{X}$ & & & & & \\
\hline Broward County, FL & & & & & & $\mathrm{X}$ & $\mathrm{X}$ \\
\hline Ft. Lauderdale, FL & $\mathrm{X}$ & $\mathrm{X}$ & $\mathrm{X}$ & $\mathrm{X}$ & $\mathrm{X}$ & & \\
\hline Hillsborough Cty, FL & & & & & & & $\mathrm{X}$ \\
\hline Miami, FL & $\mathrm{X}$ & $\mathrm{X}$ & $\mathrm{X}$ & $\mathrm{X}$ & $\mathrm{X}$ & $\mathrm{X}$ & $\mathrm{X}$ \\
\hline Palm Beach, FL & & & & $\mathrm{X}$ & $\mathrm{X}$ & $\mathrm{X}$ & $\mathrm{X}$ \\
\hline Orange County, FL & & & & & & $\mathrm{X}$ & $\mathrm{X}$ \\
\hline Orlando, FL & & & & & $\mathrm{X}$ & & \\
\hline DeKalb County, GA & & & & & & $\mathrm{X}$ & $\mathrm{X}$ \\
\hline New Orleans, LA & $\mathrm{X}$ & $\mathrm{X}$ & $\mathrm{X}$ & $\mathrm{X}$ & $\mathrm{X}$ & $\mathrm{X}$ & $\mathrm{X}$ \\
\hline Baltimore, MD & & & $\mathrm{X}$ & & & & $\mathrm{X}$ \\
\hline Boston, MA & $\mathrm{X}$ & $\mathrm{X}$ & $\mathrm{X}$ & $\mathrm{X}$ & $\bar{X}$ & $\mathrm{X}$ & $\mathrm{X}$ \\
\hline Detroit, MI & & $\mathrm{X}$ & $\mathrm{X}$ & $\mathrm{X}$ & $\mathrm{X}$ & $\mathrm{X}$ & $\mathrm{X}$ \\
\hline Jersey City, NJ & $\mathrm{X}$ & $\mathrm{X}$ & $\mathrm{X}$ & & & & \\
\hline Newark, NJ & & & $\mathrm{X}$ & & & & \\
\hline New York, NY & $\mathrm{X}$ & & $\mathrm{X}$ & $\mathrm{X}$ & $\mathrm{X}$ & $\mathrm{X}$ & $\mathrm{X}$ \\
\hline Charlotte, NC & & & & & & & $X$ \\
\hline Philadelphia, PA & $\mathrm{X}$ & $\mathrm{X}$ & $\mathrm{X}$ & $\mathrm{X}$ & $\mathrm{X}$ & $\mathrm{X}$ & \\
\hline Memphis, TN & & & & & & $\mathrm{X}$ & $\mathrm{X}$ \\
\hline Dallas, TX & $\mathrm{X}$ & $\mathrm{X}$ & $\mathrm{X}$ & $\mathrm{X}$ & $\mathrm{X}$ & $\mathrm{X}$ & $\mathrm{X}$ \\
\hline Houston, TX & & $\mathrm{X}$ & $\mathrm{X}$ & $\mathrm{X}$ & $\mathrm{X}$ & & \\
\hline Seattle, WA & $\mathrm{X}$ & $\mathrm{X}$ & & & $\mathrm{X}$ & & \\
\hline Milwaukee, WI & & & & & $\mathrm{X}$ & $\mathrm{X}$ & $\mathrm{X}$ \\
\hline
\end{tabular}

